\title{
HIGH RESOLUTION PLANKTONIC FORAMINIFERAL BIOSTRATIGRAPHY OF THE GURPI FORMATION, K/PG BOUNDARY OF THE IZEH ZONE, SW IRAN
}

\author{
BIJAN BEIRANVAND \& EBRAHIM GHASEMI-NEJAD \\ School of Geology, College of Science, University of Tehran, Tehran, Iran. biranvandb@ripi.ir
}

\begin{abstract}
Planktonic foraminiferal biostratigraphy of the Gurpi Formation at the Danial section in northeast Izeh, the Zagros Basin, Iran, provides improved age resolution and good biostratigraphic control for late Cretaceous to Paleocene strata. The section was examined based on biostratigraphy, geochemistry, and lithology. The recorded fauna are of open marine forms, and most of the Late Cretaceous-Paleocene standard tropical/subtropical planktonic foraminiferal zones are represented. The high biostratigraphic resolution represented by Plummerita hankeninoide for the Late Maastrichtian and Guembelitria cretacea for the Early Danian, together with the Ir anomaly, represent a continuous Cretaceous-Paleogene (K-Pg) succession in the studied area. The sudden extinction of 42 out of 53 species at the K-Pg boundary, especially in globotruncanids and large heterohelicids, indicates a sudden change in tropical-subtropical deep photic sea water under the mesotrophic conditions of the Late Maastrichtian. On the other hand, planktonic foraminifera experienced relatively high stress conditions during this time as indicated by the low species richness and low abundance of globotruncanids simultaneously with blooms of the disaster opportunist Guembelitria species.
\end{abstract}

Key words: biostratigraphy, K/Pg boundary, microfossils, Middle East.

RESUMO - A bioestratigrafia de foraminíferos planctônicos na seção Danial da Formação Gurpi, localizada no nordeste de Izeh, bacia de Zagros, permitiu refinar a idade e o controle bioestratigráfico dos estratos correspondentes ao Cretáceo Superior-Paleoceno. A seção foi examinada com base em bioestratigrafia, geoquímica e litologia. A fauna registrada é típica de formas de mar aberto, e corresponde à maioria das zonas padrão para foraminíferos planctônicos tropicais/subtropicais. A análise bioestratigráfica de alta resolução, que constatou Plummerita hankeninoide no Maastrichtiano superior e Guembelitria cretacea no Daniano inferior, juntamente com a anomalia de Ir, indica a presença de uma sucessão contínua do limite Cretáceo-Paleogeno (K-Pg) na área de estudo. A súbita extinção de 42 das 53 espécies no limite K-Pg, especialmente de globotruncanídeos e heterohelicídeos grandes, marca uma mudança repentina na zona fótica profunda de águas tropicais-subtropicais sob condições mesotróficas do neomaastrichtiano. Por outro lado, os foraminíferos planctônicos experimentaram condições de estresse relativamente altas durante este tempo, como indicado pela baixa riqueza de espécies e pela abundância de globotruncanídeos simultaneamente com grande proliferação de espécies oportunistas de Guembelitria.

Palavras-chave: bioestratigrafia, limite $\mathrm{K} / \mathrm{Pg}$, microfósseis, Oriente Médio.

\section{INTRODUCTION}

Development of the Zagros Basin began in the late Cretaceous due to fore deep subsidence ahead of the continental closure along the Zagros Suture (Alavi, 2004), which occurred during the Turonian to Maastrichtian collision of the western Iranian and Afro-Arabian plates (Gealey, 1988). The basin that initially developed was strongly asymmetric, being deepest along the northeastern side and a broad shallow marine shelf prevailed to the southwest (Koop \& Stoneley, 1988). The asymmetry of the basin provided a steep northwestern margin. This influenced clastic sedimentation in that coarse clastics derived from the ancestral Zagros Mountains were rapidly deposited in the basin and restricted to these marginal areas. Fine-grained clastics (muds and silts) were carried in suspension out into the central parts of the basin depositing the shaly marls of the Gurpi Formation.
The Gurpi Formation forms the upper part of the Late Cretaceous progradational-retrogradational megasequence during the latest Turonian to middle Maastrichtian and the basal strata of the overlying latest Maastrichtian to late Eocene megasequence in the Zagros Basin (James \& Wynd, 1965; Murris, 1980; Koop \& Stoneley, 1982; Ziegler, 2001; Motiei, 2003; Alavi 2004). This sequence consists of relatively deep marine shales, marls and argillaceous lime mudstones. The Gurpi Formation overlies the Ilam Formation with an age of Santonian and overlain by the Pabdeh Formation with the late Paleocene-Oligocene age at the studied section. The basal disconformity is a hematite-stained erosional surface locally associated with conglomerates composed of reworked carbonate clasts (Stoneley, 1990) and represents a hiatus of approximately 4 to 15 m.y. In the studied area, the Gurpi Formation paleontological data (Wynd, 1965) suggest that the erosional unconformity at the basal boundary represents a 
hiatus of about $10 \mathrm{~m} . y$. At the top, the boundary is generally gradational with the Pabdeh Formation. The succession, which crops out extensively among the Zagros Mountains is of particular interest due to the economic organic-rich deposits playing the role of cap for the Bangestan reservoirs in the Zagros Oil Province. Consequently, many studies have been conducted on the geology, stratigraphy, and sedimentology of the Gurpi Formation in southwest of Iran (e.g. James \& Wynd, 1965; Wynd, 1965; Sampo, 1969; Setudehnia, 1972, 1978; Stoneley, 1974, 1990; Ala et al., 1980; Zahiri, 1982; Motiei, 2003; Ghasemi-Nejad et al., 2006; Darvishzadeh et al., 2007).

According to Smit $(1982,1999,2004)$ most of Cretaceous species disappeared at the K/Pg boundary, but very few species, which are considered as reworked, crossed the boundary. Consequently the author concluded that the K/Pg mass extinction event was sudden, catastrophic and the consequence of a large extraterrestrial bolide impact. However, others (Keller, 1988, 1989a,b, 1994, 1996; Keller et al., 1994, 1995) have often questioned the catastrophic nature of the impact at the $\mathrm{K} / \mathrm{Pg}$ boundary and they argued that the pattern of the mass extinction in the terminal Maastrichtian is gradual. They noticed that $2 / 3$ of the species declined prior to becoming extinct below or at the $\mathrm{K} / \mathrm{Pg}$ boundary and about $1 / 3$ of the species survived well into the Danian. Consequently, Keller and her collaborators argued that such a gradual pattern of extinction cannot be attributed to a global biotic effect of the asteroid impact.

Despite the good distribution of planktonic foraminifera, there is no published record of this microfossil group detailing the biostratigraphy of the studied area of the Gurpi Formation. For this reason, the main objective of this study is to conduct a detailed biostratigraphic planktonic foraminiferal analysis in order to assign an age to the succession and detail the extinction pattern across the $\mathrm{K} / \mathrm{Pg}$ boundary.

\section{MATERIAL AND METHODS}

The Gurpi Formation at the Danial section consists of a sedimentary succession with a thickness of $337 \mathrm{~m}$ spanning the late Campanian to Paleocene. The section is located about 145 $\mathrm{km}$ northwest of Ahwaz city in southwest Iran. It was sampled at a locality (Pyun) about $25 \mathrm{~km}$ northwest of Izeh (Figure 1). The section was measured and sampled on the outcrop about 3 $\mathrm{km}$ northeast of the Kal-Chenar village (Figure 2). The base of the section is exactly located at $32^{\circ}, 25^{\prime}, 10^{\prime \prime} \mathrm{N}$ and $49^{\circ}, 18^{\prime}, 04^{\prime \prime} \mathrm{E}$.

A total of 164 rock samples were collected from the section at sample spacing of about $2 \mathrm{~m}$ intervals, except for the interval between sample Gu-115 and Gu-116 spanning the $\mathrm{K} / \mathrm{Pg}$ where sample spacing is about $10 \mathrm{~cm}$. In the field, the section was carefully examined for lithological changes and any evidence of stratigraphic discontinuities. In the laboratory, thin sections were prepared from all marly limestones and hard resistant shaly marl samples to achieve further evidence of microfossils, and to aid sedimentological descriptions (Figure 4). All samples were processed for foraminiferal analysis following the standard method of Keller et al. (1995). The samples disaggregated by soaking in water for several days and then washed through 200, 120,63 and $36 \mathrm{~mm}$ sieve series with tap

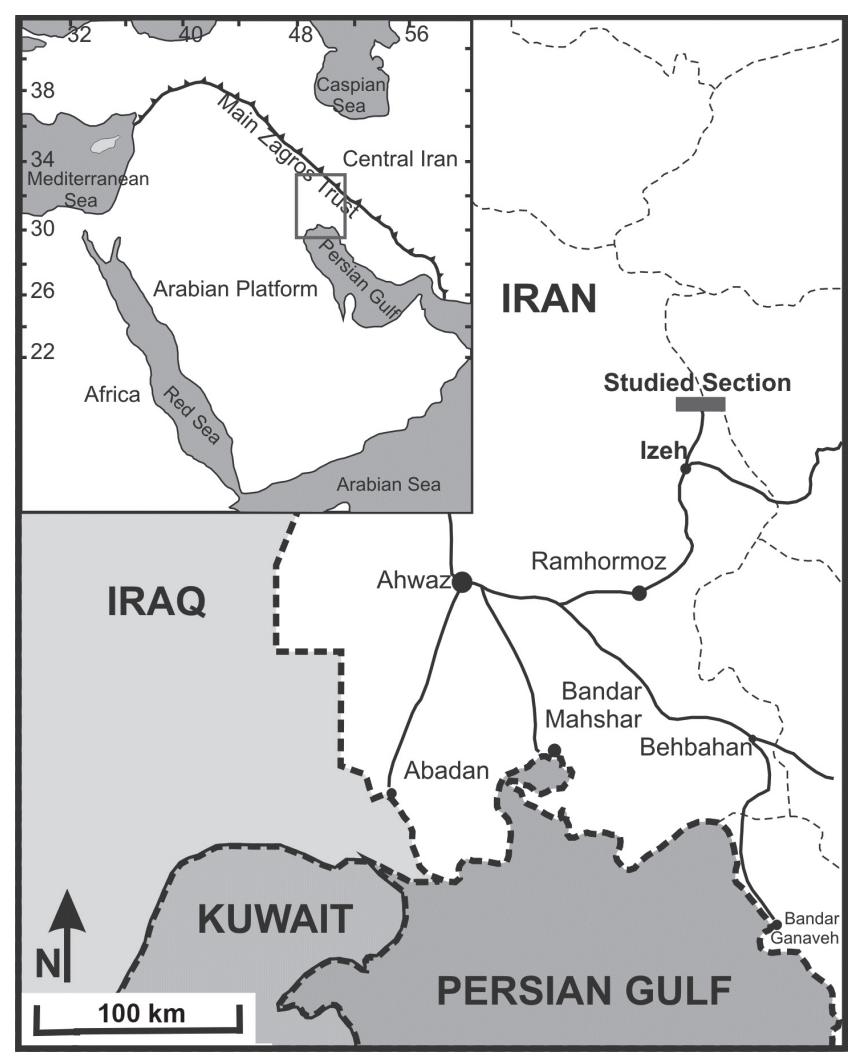

Figure 1. Geographic setting and location map of the Gurpi Formation in the study section.

water. Sediment infilling of foraminiferal tests was removed by repeated sonic agitation of the residues for about 15 seconds.

The best-preserved specimens of planktonic foraminiferal species were picked, identified and mounted on micro slides for a permanent record and taking SEM microphotographs. The relative abundance of species was noted as abundant, $>10 \%$; common, $5-10 \%$; few, $2-5 \%$; and rare, $<2 \%$. Species identification and zonal scheme (Figure 3 ) were primarily based on the studies of Caron (1985); Keller (1988); Berggren \& Miller (1988); Sliter (1989); Speijer (1994); Robaszynski \& Caron (1995); Berggren \& Norris 1997; Olsson et al. (1999); Premoli Silva \& Verga (2004); Berggren \& Pearson (2005); Gallala et al. (2009) and Gallala \& Zaghbib-Turki (2010). Thus, 53 species belonging to 24 genera of planktonic foraminifera from 11 biozones were identified. Distribution of the main species and zonal scheme are represented in Figure 5.

Major and trace element distribution around the K/Pg boundary was carried out by scanning electron microscopy (SEM) and energy-dispersive X-ray fluorescence (ED-XRF) analysis. A total of 15 finely ground bulk rock samples were selected spanning the late Maastrichtian-early Danian and analyzed at the Razi Research Institute. Furthermore, to aid the interpretation of environmental affinities, clay mineral and Total Organic Carbon (TOC) were included in the data analysis. Total organic carbon analysis was performed with a Rock-Eval III plus TOC module on powdered bulk samples, based on the analytical methods of Espitalie et al. (1986) at Research Institute of Petroleum Industry (RIPI). The results of analysis have been presented in Figure 4. 

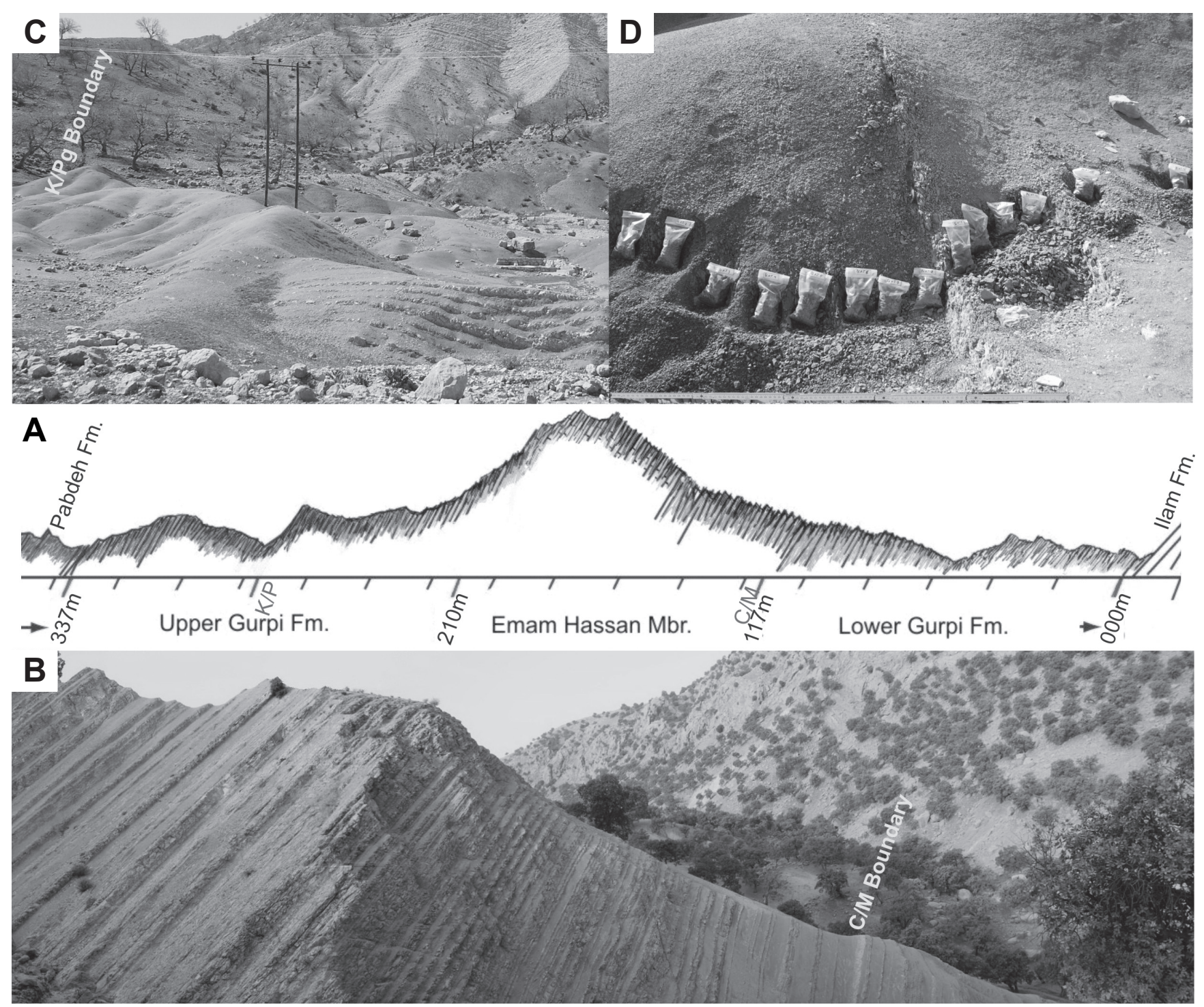

Figure 2. Outcrop of the study section. A, a sketch of the whole section; B, lower and middle part; C, upper part; $\mathbf{D}$, location of the K/Pg boundary. Thickness and time intervals for each part are represented on the figure.

\section{LITHOLOGY, FACIES AND SEA-LEVEL CHANGES}

The Gurpi Formation in the studied area consists of dark gray, greenish to dark bluish gray marine marls and shales with subordinate marly limestones (Figure 2). It can be divided into three distinctive parts. The late Campanian gray to dark gray and greenish gray shaly marls in the lower part (117 $\mathrm{m}$ thick), Maastrichtian gray marls interlayered with marly limestones of the middle part (93 m thick), and late Maastrichtian to Paleocene greenish gray to dark bluish gray shaly marl succession (127 $\mathrm{m}$ thick) in the upper part (Figure 2).

The carbonate member of Emam Hassan expands throughout the Zagros Basin and shows distinctive lateral facies variations. At the section studied, it consists of thinbedded pelagic and hemipelagic marls and argillaceous lime mudstones with planktonic foraminiferal assemblages (Wynd, 1965). This member shows a gradational contact at the base except for the lithologic color.
Paleobathymetric data (Hemati-Nasab et al., 2007) indicates that the Gurpi Formation was deposited under various environmental conditions. This study shows upper slope environmental conditions for Emam Hassan Member and middle to outer shelf depths for lower and upper parts. It indicates the similar condition to the Late Cretaceous succession in Tunisia (Keller et al., 2002). In the late Campanian interval, the succession begins with 20-60 cm thick gray to dark gray shaly marl layers, which become thicker upwards. Sediments grade from shaly marls of the lower part into the marly limestones in the middle part suggesting shallowing upward systems in this part of the sedimentary succession. The middle part of the formation (Emam Hassan Member) is marked by medium to thick-bedded gray to light gray marly limestone with interbeds of dark gray shaly marls. Up-section, sediments grade into grey marly shales (Figure 2). Clay content of the rocks increases towards the top. These levels are also indicated by presence of organic matter and bloom of heterohelicids up to the K/Pg boundary. However, The 
succession is characterized by alternating fossiliferous shaly marls and marls at the lower and upper parts during sea-level rising in dysaerobic or low oxygen conditions in upper bathyal to outer neritic environments and marly limestones belonging to outer to middle neritic environments in the middle part.
The rest of the succession represents transgressive-regressive cycles belonging to the Late Cretaceous and early Paleocene megasequences in the Zagros Basin. The megasequences coincide with the global second order supercycles of UZA-4 and TA-1 of Haq et al. (1987).

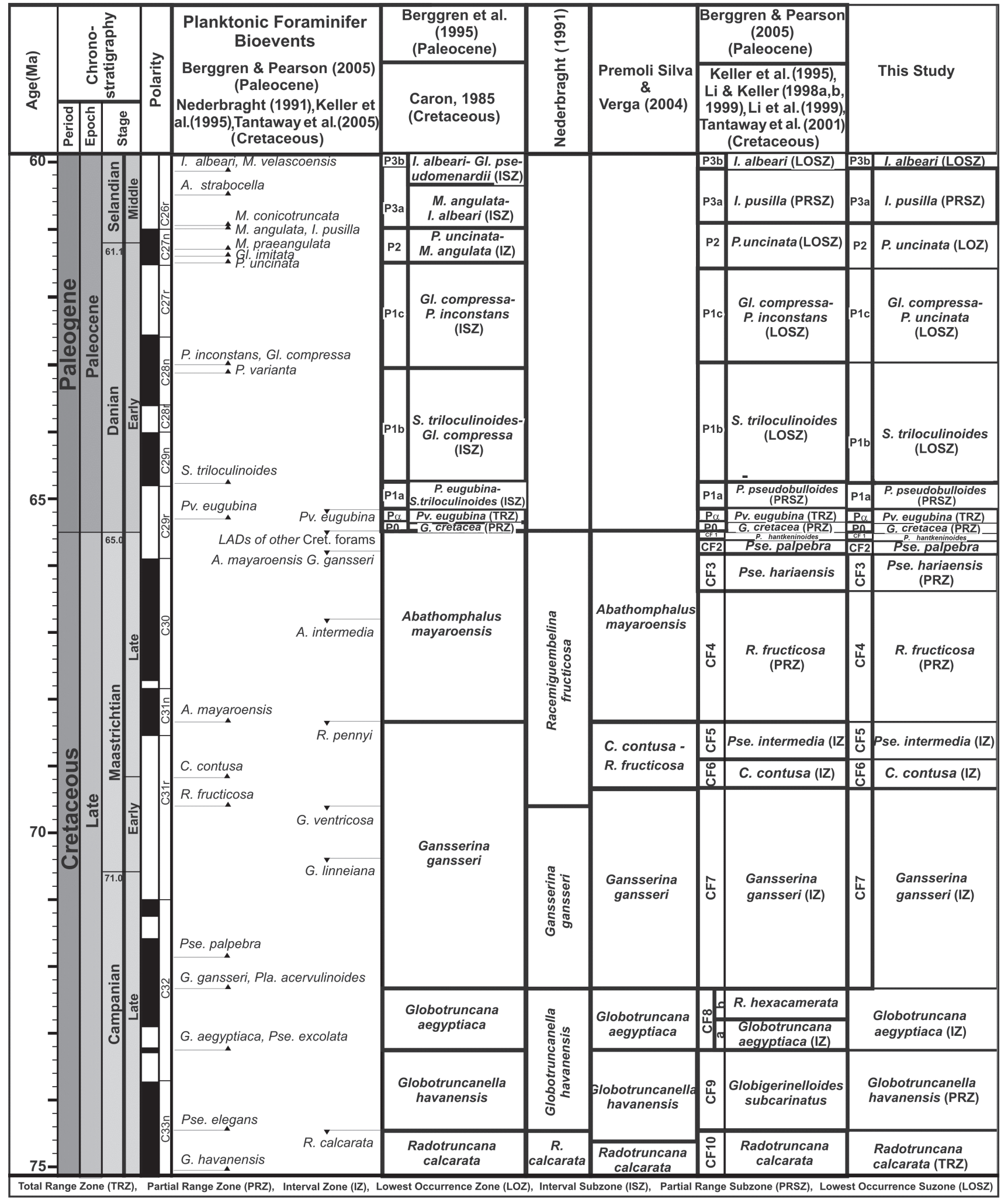

Figure 3. Late Campanian-late Selandian planktonic foraminiferal zonal schemes compared with biozones and events for the Danial section in SW Iran. 


\section{BIOSTRATIGRAPHY}

The biostratigraphic scheme, which has been chosen as framework in this study, follows the standard planktonic foraminiferal CF1-CF8 biozonation established in tropical/ subtropical regions by Li \& Keller(1998a,b) for the Maastrichtian, Caron (1985) for the Campanian and Berggren et al. (1995) and Keller et al. (1995) for the Paleocene (Figure 3). Of the 18 late Campanian to late Selandian biozones currently erected for sedimentary successions in the North Mid Latitudes and the Tethyan Realm, 12 zones and nine subzones were recorded in the section studied. Darvishzadeh et al. (2007) were able to differentiate 18 planktonic foraminiferal zones in SW Iran from a different section. These two zonal schemes are the same except for the interval encompassed by two late Maastrichtian zones of Abathomphalus mayaroensis and Contusotruncana contusa-Racemiguembelina fructicosa by Caron (1985) that are subdivided by Li \& Keller (1998a,b) into four (CF1CF4) and two (CF5-CF6) biozones, which were recognized by Darvishzadeh et al. (2007) as well as in this study. The planktonic foraminiferal assemblages from the Gurpi Formation in the Zagros Basin are of typical Tethyan character. The marker species identified in the study are illustrated in Figures 6-12.

The zones and subzones, which have been identified here, clearly show a similar sequence of correlatable bioevents.

\section{Radotruncana calcarata Taxon Range Zone}

Radotruncana calcarata TRZ (Figure 4) is defined as biostratigraphic interval from the lowest occurence (LO) to the highest occurence (HO) of the nominate taxon, and corresponds to the early late Campanian (Caron, 1985; Premoli Silva \& Sliter, 1994; Keller et al., 1995; Li \& Keller, 1998a,b; Li et al., 1999; Robaszynski et al., 2000; Tentaway et al., 2001; Premoli Silva \& Verga, 2004).

In the studied section, the main part of the Radotruncana calcarata TRZ is missing due to the disconformity between Ilam and Gurpi formations. Therefor, many early and middle Campanian species simultaneously disappear at the formation boundary. The biozone corresponds to the base of the Gurpi Formation and indicates a late Campanian age. The nominate taxon is rare and predominant species of the zone are Globotruncana arca, G. bulloides, G. lapparenti, G. linneiana, G. mariei, G. falsostuarti, Globotruncanella havanensis, Globotruncanita stuartiformis, Contusotruncana fornicata, C. plummerae, Radotruncana subspinosa, Rugoglobigerina rugosa, Archaeoglobigerina cretacea, Heterohelix globulosa, and $H$. punctulata. This zone is represented by basal $10 \mathrm{~m}$ of dark gray shaly marls (Figure 4).

\section{Globotruncanella havanensis Partial Range Zone}

The Globotruncanella havanensis PRZ represents the stratigraphic interval with $G$. havanensis between the $\mathrm{HO}$ of Radotruncana calcarata and the LO of Globotruncana aegyptiaca. The zone corresponds to the late Campanian (Caron, 1985; Permoli Silva \& Verga, 2004). Predominant species include Archaeoglobigerina blowi, Globotruncana arca, G. bulloides, G. lapparenti, G. linneiana, G. falsostuarti,
Globotruncanita stuarti, G. stuartiformis, Planoglobulina carseyae, P. brazoensis, Pseudoguembelina costulata, Radotruncana subspinosa, Rugoglobigerina rugosa, Heterohelix punctulata, and H. globulosa. The nominate taxon is rarely recorded in the studied section and the most common species of the zone include Globotruncana bulloides, G. stuarti, G. stuartiformis, and R. rugosa. The zone is approximately equal to the combined $G$. havanensis and G. aegyptiaca zones of Caron (1985) and Globotruncanita stuartiformis PRZ of Caron (1978) Tethyan zonal scheme. This biostratigraphic interval includes $40 \mathrm{~m}$ of dark gray marls to shaly marls in the Lower Gurpi Formation and was recognized based on 14 samples (Gu006-Gu019) analyzed (Figure 4).

\section{Globotruncana aegyptiaca Interval Zone, CF8 of Li \& Keller (1998a,b)}

The Globotruncana aegyptiaca IZ is defined as the interval from the LO of $G$. aegyptiaca to the LO of Gansserina gansseri. In this study, the first appearance of Globotruncanella petaloidea and Rugoglobigerina macrocephala accompanying $G$. aegyptiaca and the planktonic foraminiferal assemblage of Globotruncanella havanensis PRZ indicates the Late Campanian age (Caron, 1985; Premoli Silva \& Sliter, 1994; Keller et al., 1995; Li \& Keller, 1998a,b; Li et al., 1999; Robaszynski et al., 2000; Tentaway et al., 2001; Premoli Silva \& Verga, 2004). This interval is indicated by abundance of the nominate taxon and includes $30 \mathrm{~m}$ of greenish gray clayey marls of the lower Gurpi formation in the studied section. A total of 11 samples (Gu020-Gu030) were analyzed in this zone (Figure 4).

\section{Gansserina gansseri Interval Zone, CF7 of Li \& Keller (1998a,b)}

The Gansserina gansseri IZ has been defined as an interval between the LO of G. gansseri to the LO of Contusotruncana contusa. It indicates the latest Campanian to the end of early Maastrichtian (Robaszynski et al., 1984; Caron, 1985; Sliter, 1989; Nederbraght, 1991; Robaszynski \& Caron, 1995; Keller et al., 1995; Li \& Keller, 1998a,b; Li et al., 1999; Robaszynski et al., 2000; Tentaway et al., 2001; Premoli Silva \& Verga, 2004). In this study, the upper limit of the zone was indicated by the first appearance of Contusotruncana contusa as a following Li \& Keller (1998a, b).

In addition to the associated species of the Globotruncana aegyptiaca interval zone, Rugoglobigerina hexacamerata, R. milamensis, Pseudoguembelina excolata, and Racemiguembelina powelli are the predominant forms in this zone. This interval zone consists of 41 samples (Gu031Gu071) and encompasses a $109 \mathrm{~m}$ thick sequence comprising the upper $39 \mathrm{~m}$ of the lower unit and $70 \mathrm{~m}$ of the middle part of the Gurpi Formation (Figure 4).

\section{Contusotruncana contusa Interval Zone, CF6 of $\mathrm{Li} \&$ Keller (1998a,b)}

This concurrent range zone represents the stratigraphic interval that includes simultaneously occurrences of 


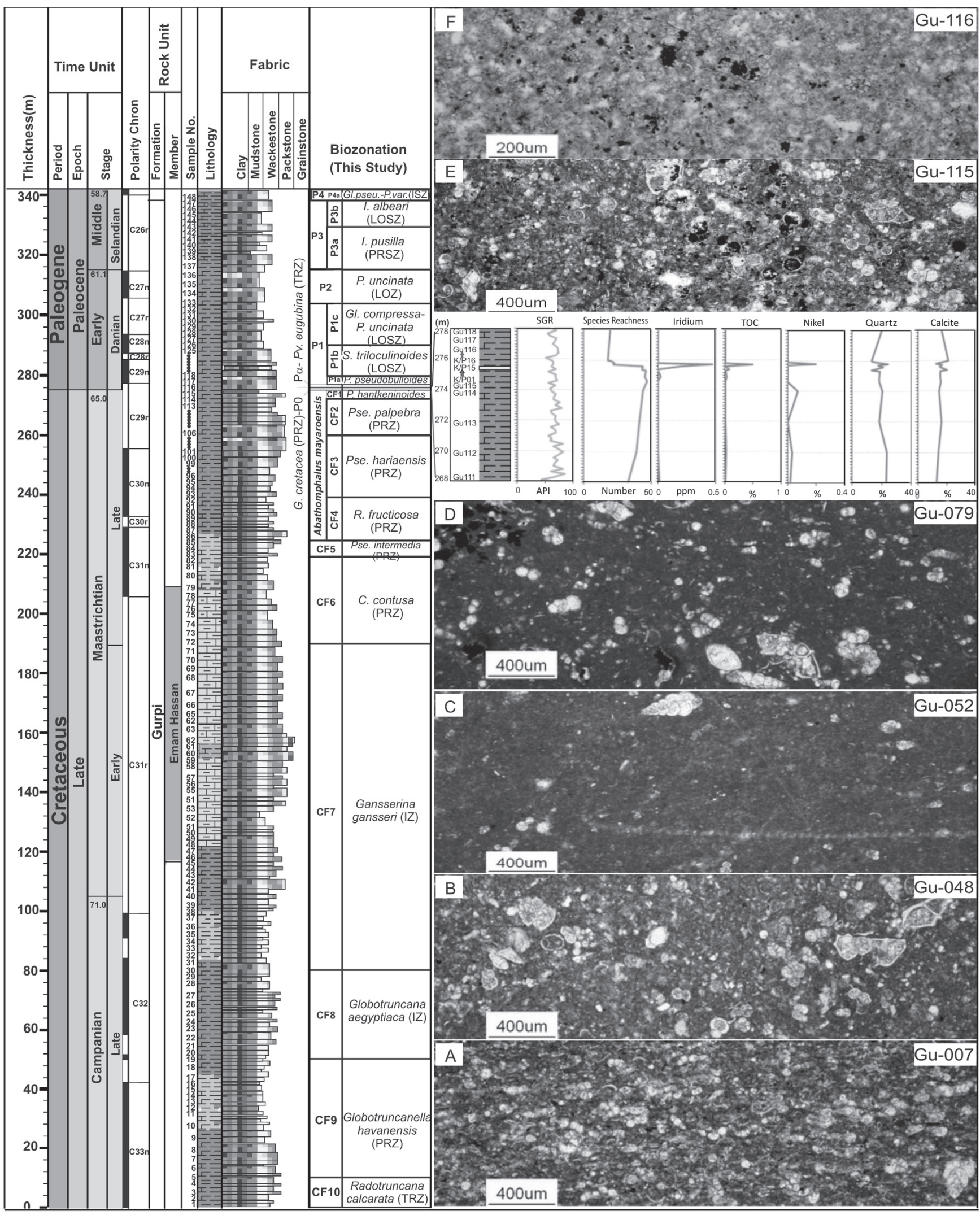

Figure 4. Detail of the section, showing planktonic foraminiferal zonation against time and rock units, lithologic column, textural variations and sample number, in the left hand, and photomicrographs illustrating the main microfacies types of the section and geochemical analysis curves around the K/Pg boundary, in the right hand. Main types of microfacies in the sedimentary succession: A, E, packstone; B, wackeston/ packstone; C, pelagic foraminifera mudston; D, F, wackeston. Photomicrographs E and F (belonging to CF1 and Pa biozones) are showing the main differences in abundance and size of the planktonic foraminifera aroud the K/Pg boundary. 
Contusotruncana contusa and Globotruncana linneiana between the LO of C. contusa to the HO of Globotruncana linneiana following Li \& Keller (1998a,b) and Wonders (1992). The associated species of this interval are the same as the Gansserina gansseri interval zone. Heterohelicids, rugoglobigerinids and globigerinelloids are common to abundant groups in the biozone. In addition, keeled globotruncanids are present but they have declined in number. A total of 11 samples (Gu072-Gu082) were analyzed from $30 \mathrm{~m}$ thick of the zone. This zone comprises marly limestone and marls of the upper most part of the middle Gurpi Formation (Figure 4).

\section{Pseudotextularia intermedia Partial range Zone, CF5 of Li \& Keller (1998a,b)}

This statigraphic interval is defined as the partial range of Pseudotextularia intermedia between the $\mathrm{HO}$ of Globotruncana linneiana at the base and the LO of Racemiguembelina fructicosa at the top and corresponds to the late Maastrichtian (Li \& Keller, 1998a). The predominant planktonic foraminifera associated with the nominate taxon are the Contusotruncana contusa PRZ assemblages except for G. linneiana and Globotruncana ventricosa species. Pseudotextularia intermedia appears in the zone CF6, but its typical morphotypes are well-developed in CF5. This biozone spans $6 \mathrm{~m}$ of gray to greenish gray clayey marls and marls (Figure 4). P. intermedia is a common species in the zone where the keeled globotruncanids are declined.

\section{Abathomphalus mayaroensis Total range Zone}

Abathomphalus mayaroensis TRZ has been defined as the total range of nominated taxon belonging to the late Maastrichtian. This zone was defined for the first time by Bolli (1957) from the uppermost Maastrichtian of Trinidad. Robaszynski \& Caron (1995) proposed the A. mayaroensis Zone as a partial range zone spanning the first occurrence of the species to the last occurrence of most globotruncanids of low to middle latitude in the entire Mediterranean-European area. Many workers (Keller et al., 1995; Molina et al., 1996; Pardo et al., 1997; Li \& Keller, 1999) introduced the Plummerita hantkeninoides total range zone for the uppermost Maastrichtian sediments because of rareness of A. mayaroensis in this part of the zone.

In this investigation, the Abathomphalus mayaroensis biostratigraphic interval is introduced as a taxon-range zone of $A$. mayaroensis. It is characterized by very high diversity of ornate, large, and tropical to subtropical deep-water dwelling forms. Despite limitation of the keeled forms and their decrease slightly towards the top of the zone, the bulk of unkeeled morphologically simple forms such as biserial heterohelicids and hedbergellids are increasing (Figures 4). Its predominant planktonic foraminifera are: Archaeoglobigerina blowi, Contusotruncana contusa, Globotruncana arca, G. falsostuarti, Globotruncanita stuarti, G. stuartiformis, G. conica, Gansserina gansseri, Guembelitria irregularis, Guembelitria cretacea, Planoglobulina carseyae, Psedugumbelina brazoensis, Pse. hariaensis, Pse. palpebra, Pse. intermedia, Pse. elegans, Racemiguembelina fructicosa, Rugoglobigerina reicheli,
R. rugosa, R. macrocephala, Trinitella scotti, Heterohelix globulosa, and Hedbergella holmdelensis.

In the upper part of the zone, the nominate taxon is scarce but the forms are larger in size. This zone attains a thickness of $53 \mathrm{~m}$ of greenish gray to dark and bluish gray marls and clayey marls at the latest Cretaceous part of the Gurpi Formation (Figure 4). To evaluate the nature and continuity of the sedimentary record, the biostratigraphy is evaluated based on the Cretaceous foraminiferal (CF) zonal scheme of Li \& Keller (1998a,b, 1999). Therefore to provide much improved age control for the late Maastrichtian, the Abathomphalus mayaroensis TRZ is equivalence to the four zones of CF1CF4. These zones from bottom to top are as follow below.

\section{Racemiguembelina fructicosa Partial range Zone, CF4 of Li \& Keller (1998a,b)}

This zone is a stratigraphic interval limited between the LO of $R$. fructicosa and the LO of Pseudoguembelina hariaensis (Li \& Keller, 1998a). Most of the Late Cretaceous species except Trinitella scotti, Psedugumbelina hariaensis, Pse. palpebra, Guembelitria irregularis, and G. cretacea are the predominant planktonic foraminifera of the zone. Racemiguembelina fructicosa IZ was named by Li \& Keller (1998a) as CF4. This biozone was defined based on 7 samples (Gu086-Gu092) analyzed. It consists of $14 \mathrm{~m}$ thick gray to greenish gray of clayey marls in the section (Figure 4).

\section{Pseudoguembelina hariaensis Partial range Zone, CF3 of Li \& Keller (1998a,b)}

This partial range zone characterized by the LO of nominate taxon at the base and the $\mathrm{HO}$ of Gansserina gansseri at the top (Li \& Keller, 1998a). The predominant planktonic foraminiferal association of the zone is Abathomphalus mayaroensis TRZ assemblages except Plummerita hantkeninoides, Guembelitria irregularis, and G. cretacea species. The zonal marker is easily recognizable and relatively abundant in this zone. The zone spans $21 \mathrm{~m}$ of gray to greenish gray clayey marls (Figure 4 ).

\section{Pseudoguembelina palpebra Partial range Zone, CF2 of Li \& Keller (1998a,b)}

A partial range of nominate taxon has been limited between the HO of Gansserina gansseri and LO of Plummerita hantkeninoides (Li \& Keller, 1998a). Pseudoguembelina palpebra is associated with the Abathomphalus mayaroensis TRZ assemblages except $G$. gansseri in this partial range zone. The nominate taxon is an abundant species in the studied section. The partial range zone comprises $12 \mathrm{~m}$ thick dark gray clayey marl and shale (Figure 4). The abundance of the species represents the highest sedimentation rate.

\section{Plummerita hantkeninoides Total-range Zone, CF1 of Li \&Keller (1998a,b)}

This biozone is defined as stratigraphic interval comprising the total range of Plummerita hantkeninoides with latest Maastrichtian (Li \& Keller, 1998a). This biostratigraphic interval was proposed by different authors (Masters, 1984; 
Keller et al., 1995; Molina et al., 1996; Pardo et al., 1996) due to rareness of Abathomphalus mayaroensis in the upper part of the A. mayaroensis TRZ. Li \& Keller (1998a) introduced this biozone as CF1 for the first time. On the other hand, they proposed the $P$. hantkeninoides TRZ rather than the Pseudotextularia deformis IZ because of its wider application and to the localized presence of the last occurrence of $A$. mayaroensis below the $\mathrm{K} / \mathrm{Pg}$ boundary.

The predominant planktonic foraminifera in this interval are Globotruncana falsostuarti, Heterohelix navarroensis, H. globulosa, H. dentate, Pseudoguembelina costulata, Pse. elegans, Pse. intermedia, and Plummerita reicheli. A large number of the Late Cretaceous species are recognized in the late Maastrichtian in the Plummerita hantkeninoides TRZ (Figure 5). Hedbergella monmouthensis is quite common but large keeled forms represent a minor part of the population. Guembelitrids, including Guembelitria cretacea, are not abundant in the uppermost Maastrichtian. The nominate taxon with a short and/or broken apical spine provides a good estimate of the completeness of the latest Maastrichtian interval. It is abundant but not good preserved here. The zone consists of $3 \mathrm{~m}$ thick dark gray organic rich clayey marls and was defined based on 7 samples $(\mathrm{K} / \mathrm{P} 01-\mathrm{K} / \mathrm{P} 15)$ at the latest Maastrichtian stratigraphic interval (Figures 4, 5).
Guembelitria cretacea Partial-range Zone (P0)

This biozone is a partial range of Guembelitria cretacea which has been defined from the HO of large, more ornate Maastrichtian taxa (e.g. Globotruncana, Rugoglobigerina, Globigerinelloides) to the LO of Parvularugoglobigerina eugubina. The Guembelitria cretacea PRZ was first defined as the interval ranging from the $\mathrm{K} / \mathrm{Pg}$ boundary to the first occurrence of the Tertiary species (Smit, 1982). Then, it was modified by Keller (1988) into two subdivisions including the P0a (G. cretacea) and P0b (Globoconusa conusa) subzones, but subsequently revised as $\mathrm{P} 0$ from the mass extinction of Maastrichtian species to the LO of $P$ v. eugubina and/or Pv. logiapertura (Keller et al., 1995). D'Hondt \& Keller (1991) and Pardo et al. (1996) defined the P0 Zone as the partial range of $G$. cretacea following the extinction of large, more ornate Maastrichtian globotruncanids, and preceding the first appearance of $P v$. eugubina. Finally, it was defined by Berggren \& Pearson (2005) as a partial range of $G$. cretacea from the $\mathrm{HO}$ of Cretaceous taxa (e.g. Globotruncana, Rugoglobigerina, Globigerinelloides) to the LO of Pv. eugubina. However, the successive occurrence of $P$ v. longiapertura and $P v$. eugubina was also noted in the Elles (Tunisia), Ain Settara (Tunisia), and the Caravaca and Agost sections in Spain (Keller et al., 1995; Molina et al.,

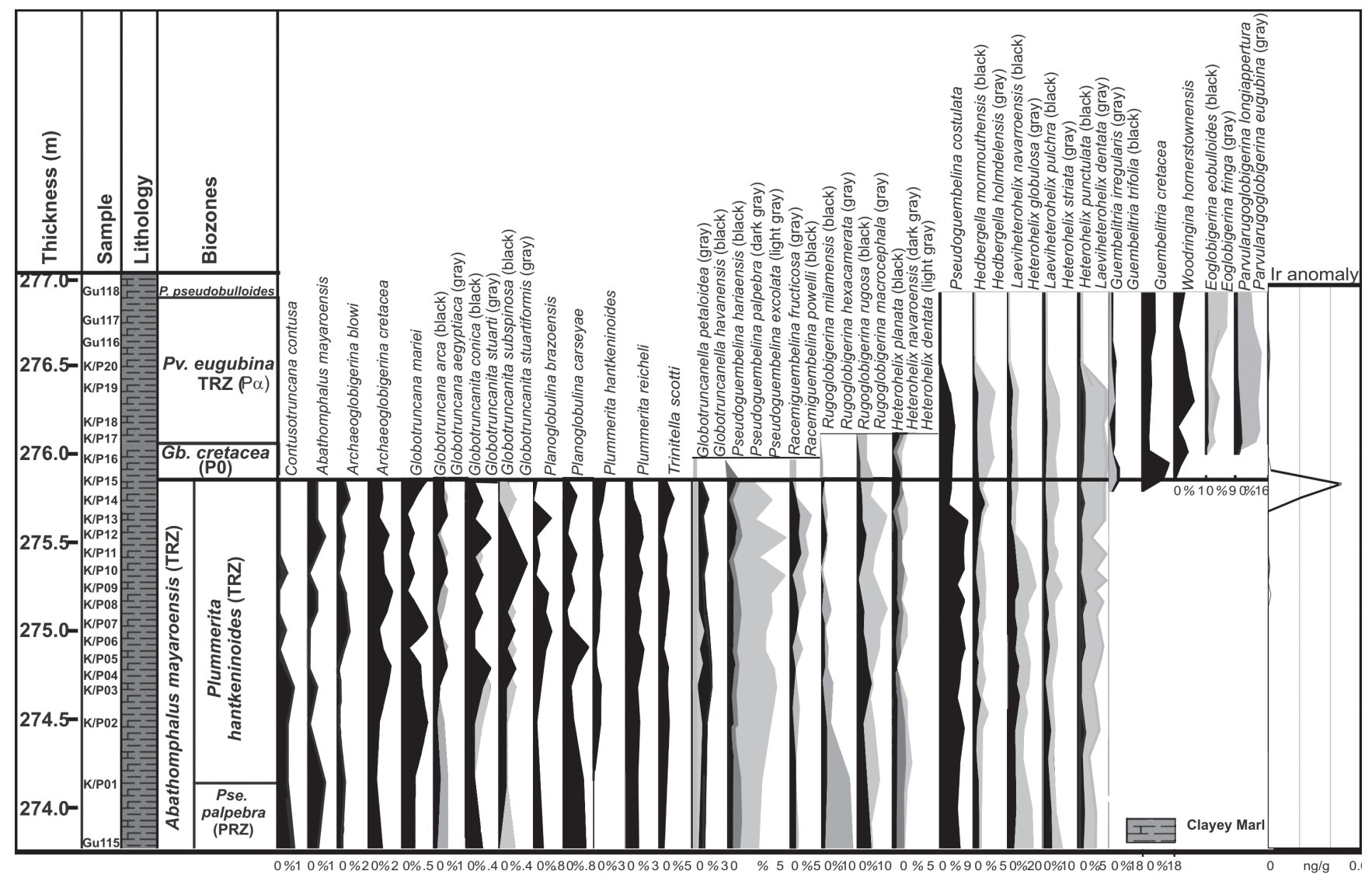

Figure 5. Species distribution of the Cretaceous planktonic foraminifera across the K/Pg boundary at Danial section in SW Iran. Details of lithology, sample intervals, and biozones have been represented against the relative species abundances of Cretaceous survivors and evolving early Tertiary planktonic foraminifera in uppermost Maastrichtian and lowermost Danian sediments. All the considered species are tropical to subtropical with combined total abundance less than $25 \%$ of the Cretaceous assemblage. Faunal counts are based on the $>63 \mathrm{~mm}$ size fraction exception of species in P0 and the lower part of $\mathrm{Pa}$ biozones which are nearly absent in this size fraction. The peak of the Ir anomaly is the other acceptable evidence for the K/Pg boundary location. 
1996; Arenillas et al., 2004) and its magnetostratigraphic position is in Chron C29r and its duration is between 65.000 and 64.981 Ma (Berggren et al., 1995, Olsson et al., 1999).

The predominant species of the interval contains a few new Tertiary species such as Parvularugoglobigerina longiapertura, Eoglobigerina fringa, Woodringina hornerstownensis and large number of heterohelisids. Although the first appearance of $W$. hornerstownensis happens at the top of the Maastrichtian, but some authors believe that this species appears above the base of the Parvularugoglobigerina eugubina zone and has never been found in the uppermost Cretaceous nor in P0 (Olsson et al., 1999). However, in the current study, W. hornerstownensis is found in the P0. The biozone generally spans the interval, from the $\mathrm{HO}$ of Plummerita hantkeninoides to the LO of $P v$. eugubina (as defined in Keller et al., 1995). P0 zone at the section comprises $23 \mathrm{~cm}$ of dark gray organic rich shaly marl including $46 \%$ of the latest Maastrichtian species (Figure 5). Hedbergella monmouthensis and $H$. holmdelensis, as well as Guembelitria cretacea, are survivors into the P0.

\section{Parvularugoglobigerina eugubina Total range Zone (Pa)}

This is a biostratigraphic interval characterized by the total range of the Parvularugoglobigerina eugubina. Luterbacher \& Premoli Silva (1964) placed the LO of Pv. eugubina at the $\mathrm{K} / \mathrm{Pg}$ boundary and regarded it at the lowermost Danian. The zone was commonly used for the early Danian just above the Guembelitria cretacea PRZ (Toumarkine \& Luterbacher 1985; Keller 1988; Berggren et al., 1995; Keller et al., 1995) just like what we found in the section studied.

In the section studied, the main components of the zone are Chiloguembelina midwayensis, Eoglobigerina eobulloides, Guembelitria trifolia, G. cretacea, Subbotina trivialis, and Woodringina hornestownesis. Parvularugoglobigerina eugubina as the main elements in the zone show variability in size, number of chambers, and height of whorl. This variability is mainly related to evolutionary and environmental causes (Liu \& Olsson, 1992). Appearance of E. eobulloides and increase in size of the Tertiary species happens in the upper part of the zone. However, the first appearance of $S$. trivialis in the studied section is lower than LO of E. eobulloides. This is according to Olsson et al. (1999). They proposed that, stratigraphically older or shallower-water forms of $E$. eobulloides show a higher trochospire and fewer chambers in each whorl than younger members and/or pelagic dwellers. At the base of the zone, the bulk of the planktonic foraminiferal population still consists of small and unkeeled late Cretaceous forms, especially heterohelicids and globigerinelloids. This zone consists of $100 \mathrm{~cm}$ thick organic rich bluish gray shaly marls which is defined based on 6 samples $(\mathrm{K} / \mathrm{P} 17-\mathrm{K} / \mathrm{P} 20$ and Gu016-017) at the base of Danian. It is containing about $36 \%$ of the latest Maastrichtian species (Figure 5).

\section{Parvularugoglobigerina eugubina-Praemurica uncinata Zone (P1)}

This biostratigraphic interval ranges from the $\mathrm{HO}$ of Parvularugoglobigerina eugubina to the LO of Praemurica uncinata. It is emendation of Subbotina pseudobulloidesGloboconusa daubjergensis Zone (P1) of Berggren \& Miller (1988) that renamed it the Eoglobigerina edita Partial-range Zone by Berggren \& Pearson (2005). They divided it into three subzones. Parasubbotina pseudobulloides PRSZ (P1a) below, Subbotina triloculinoides LOSZ (lowest-occurrence subzone) (P1b) at the middle and Globanomalina compressa/Praemurica inconstans-P. uncinata Subzone (P1c) above. Later, Gallala \& Zaghbib-Turki (2010) divided the Ps. pseudobulloides Zone of Arenillas et al. (2004) into the Subbotina trivialis and $S$. triloculinoides subzones. The former corresponds to the interval between the $\mathrm{HO}$ of Pv. eugubina and the LO of $S$. triloculinoides, whereas the latter spans the interval between the LO of S. triloculinoides and the LO of Gl. compressa.

In this study, the common associated species are Eoglobigerina eobulloides, E. spiralis, Globanomalina planocompressa, Gl. imitata, Globoconusa daubjergensis, Parasubbotina pseudobulloides, Ps. varianta, Praemurica pseudoinconstans, $P$. inconstans, $P$. taurica, and Subbotina triloculinoides. The zone attains $27 \mathrm{~m}$, comprises $4 \mathrm{~m}, 9 \mathrm{~m}$, and $15 \mathrm{~m}$ gray to dark gray shaly marls for $\mathrm{P} 1 \mathrm{a}, \mathrm{P} 1 \mathrm{~b}$, and $\mathrm{P} 1 \mathrm{c}$ respectively in the upper part of the Gurpi Formation in early Danian (Figure 4). A total of 12 samples were analyzed in this zone.

\section{Parasubbotina pseudobulloides Partial-range Subzone (P1a)}

It is a stratigraphic interval which has been defined as the partial range of Parasubbotina pseudobulloides, from the $\mathrm{HO}$ of Parvularugoglobigerina eugubina to the LO of Subbotina triloculinoides and corresponds to the Danian (Berggren \& Miller, 1988; Berggren et al., 1995; Berggren \& Pearson, 2005). This zone renamed from Parvularugoglobigerina eugubina-Subbotina triloculinoides zone (P1a) of Berggren et al. (1995) emendation of Subbotina pseudobulloidesGloboconusa daubjergensis Zone (P1) of Berggren \& Miller (1988) into the Eoglobigerina edita Partial-range Zone by Berggren \& Pearson (2005). Characteristic elements of this subzone include: Eoglobigerina eobulloides (spinose eoglobigerinids), Ps. pseudobulloides (parasubbotinids), Praemurica pseudoinconstans and P. taurica (nonspinose praemorozovellids), Globanomalina planocompressa (globanomalinids), G. daubjergensis and different kinds of heterohelicids. The common associated species of PS. pseudobulloides in the studied section are E. eobulloides, $P$. pseudobulloides, Praemurica pseudoinconstans, P. taurica, and Gl. planocompressa. The nominate taxon is a common component of the subzone. Berggren et al. (1995) gave an age of 64.8-64.3 Ma to the original definition of this subzone.

\section{Subbotina triloculinoides Lowest Occurrence Subzone (P1b)}

This biostratigraphic subzone is a partial range of Subbotina triloculinoides taxon limited between the LO of $S$. triloculinoides and the LO of Globanomalina compressa and corresponds to the Danian (Berggren \& Miller, 1988; Berggren et al., 1995; Berggren \& Pearson, 2005). Eoglobigerina eobulloides, Parasubbotina pseudobulloides, Praemurica 
pseudoinconstans, P. taurica, P. inconstans, Globoconusa daubjergensis, and Globanomalina planocompressa are associated species of Ps. pseudobulloides in the subzone. The common species of the subzone are E. eobulloides, $P_{S}$. pseudobulloides, and Gl. planocompressa. Species of $G$. daubjergensis, $P$. taurica, and $P$. inconstans are present rarely.

\section{Globanomalina compressa/Praemurica uncinata Lowest Occurrence Subzone (P1c)}

It is a biostratigraphic interval identified by two datum events. The first is the LO of Globanomalina compressa and Parasubbotina varianta at the lower limit and the second is the LO of P. uncinata and P. praecursoria at the upper limit which corresponds to the middle to late Danian (Berggren \& Miller, 1988; Berggren et al., 1995; Berggren \& Pearson, 2005).

Associated species in the section are Eoglobigerina spiralis, Globanomalina planocompressa, Gl. imitata, Globoconusa daubjergensis, Parasubbotina pseudobulloides, Ps. varianta, Praemurica pseudoinconstans, P. inconstans, and Subbotina triloculinoides. But the common species of the subzone are Ps. pseudobulloides, S. triloculinoides, Globanomalina compressa, and Parasubbotina varianta. Two specimens of $G$. daubjergensis and Gl. planocompressa have been only recorded at the base and E. spiralis was found at the top of the subzone.

\section{Praemurica uncinata Lowest Occurrence Zone (P2)}

A biostratigraphic interval defined as a partial range of nominate taxon between the LO of Praemurica uncinata and the LO of Morozovella angulata and corresponds to the late Danian (Berggren \& Miller, 1988; Berggren et al., 1995, 2000; Berggren \& Pearson, 2005). This zone can be correlated with the Morozovella uncinata-Igorina spiralis zone (P2) of Berggren \& Miller (1988) that was emended by Berggren et al., 1995 and renamed as Praemurica uncinata Lowestoccurrence zone by Berggren \& Pearson (2005) (Figure 3).

Associated species of the nominate taxon are Eoglobigerina spiralis, Globanomalina compressa, Gl. imitata, Morozovella praeangulata, Parasubbotina pseudobulloides, Ps. variospira, Praemurica inconstans, P. praecursoria, Subbotina triangularis and $S$. cancellata. The common components of the zone are Praemurica uncinata, M. angulata, and $M$. praeangulata. Species of $S$. triangularis appears only at the top of the zone. This zone consists of $11 \mathrm{~m}$ dark gray to reddish gray clayey marl at the upper part of the Gurpi Formation (Figure 4).

\section{Morozovella angulata Lowest Occurrence Zone (P3)}

This zone is a stratigraphic interval between the LO of Morozovella angulata at the bottom and the LO of Globanomalina pseudomenardii at the top and corresponds to the Selandian (Berggren \& Miller, 1988; Berggren et al., 1995, 2000; Berggren \& Pearson, 2005). The zone was first proposed as Globorotalia pusilla pusilla Zone for the biostratigraphic interval between LO of Globorotalia uncinata and LO of $\mathrm{Gl}$. pseudomenardii by Bolli (1957). The LO of Igorina albeari is now known to occur approximately midway between that of
Igorina pusilla and Gl. pseudomenardii (Berggren et al., 1995, 2000). Thus, a two-fold subdivision of Zone P3 was made by Berggren et al. (1995). The lower subzone was designated the Morozovella angulata-Igorina albeari Interval Subzone (P3a) and the upper one designated the Igorina albeariGlobanomalina pseudomenardii Subzone (P3b). This zone was renamed to Morozovella angulata zone by Berggren \& Pearson (2005). The age estimated for the zone is 61.0-59.4 Ma (Berggren et al., 2000).

Associated species of the nominate taxon in the studied section are: Acarinina strabocella, Globanomalina compressa, Gl. chapmani, Gl. imitata, Igorina pusilla, Morozovella angulata, M. apanthesma, M. conicotruncana, M. praeangulata, M. velascoensis, Parasubbotina pseudobulloides, Ps. varianta, Ps. variospira, Praemurica inconstans, P. praecursoria, Subbotina cancellata, $S$. triangularis, $S$. triloculinoides, and $S$. velascoensis. Totally 11 samples (Gu137-Gu147) were analyzed in this zone. The zone comprises $23 \mathrm{~m}$ of gray to reddish gray clayey marl at the upper most part of the Gurpi Formation (Figure 4).

\section{Igorina pusilla Partial range Subzone (P3a)}

This biostratigraphic sub zone is an interval defined as a partial range of Igorina pusilla between the LO of Morozovella angulata and LO of Igorina albeari (Bolli, 1957; Berggren \& Miller, 1988; Berggren et al., 1995; Berggren \& Pearson, 2005; Soldan et al., 2011). The zone was renamed from the Morozovella angulata-Igorina albeari Subzone of Berggren et al. (1995).

The assemblage comprises Acarinina strabocella, Globanomalina compressa, Gl. imitata, Morozovella angulata, M. conicotruncana, M. praeangulata, Parasubbotina pseudobulloides, Ps. varianta, Ps. variospira, Praemurica inconstans, P. praecursoria, Subbotina cancellata, S. triangularis, and $S$. triloculinoides. Morozovella angulata, $M$. praeangulata, I. pusilla, S. triangularis, and S. triloculinoides are common components of the zone. Based on the assemblage and the planktonic foraminiferal events, the age estimated for the subzone is Selandian (Berggren \& Pearson, 2005). This subzone comprises $14 \mathrm{~m}$ gray to reddish gray clayey marl at the uppermost part of the Gurpi Formation (Figure 4).

\section{Igorina albeari Lowest-occurrence Subzone (P3b)}

A biostratigraphic interval between the LO of Igorina albeari and the LO of Globanomalina pseudomenardii (Berggren \& Miller, 1988; Berggren et al., 1995; Berggren \& Pearson, 2005). This subzone is biostratigraphically identical to the Igorina albeari-Globanomalina pseudomenardii Interval Subzone (P3b) of Berggren et al. (1995).

The associated species of the zone in the studied section are Acarinina strabocella, Globanomalina imitata, Gl. chapmani, Igorina pusilla, Morozovella angulata, M. apanthesma, $M$. conicotruncana, M. velascoensis, Parasubbotina varianta, Ps. variospira, Subbotina cancellata, S. triangularis, S. triloculinoides, and $S$. velascoensis; and common components are $M$. angulata, I. pusilla, S. triangularis, S. velascoensis, and $S$. triloculinoides. Globanomalina chapmani and 
M. velascoensis appear at the upper part of the subzone. Accordingly, the age estimated for the subzone is Selandian (Berggren \& Pearson, 2005). This subzone consists of $9 \mathrm{~m}$ reddish gray clayey shale and marl at the uppermost part of the Gurpi Formation (Figure 4).

\section{CHRONOSTRATIGRAPHIC BOUNDARIES}

\section{The Campanian-Maastrichtian boundary}

The extinction of Radotruncana calcarata had long been used to draw the Campanian-Maastrichtian boundary (Robaszynski et al., 1984; Caron, 1985; Almogi-Labin et al., 1986; Sliter, 1989). Robaszynski \& Caron (1995) proposed that $R$. calcarata disappeared before the base of the Nostoceras hyatti Zone (ammonite zone dating uppermost Campanian). Gradstein et al. (1995) estimated the age younger than $\mathrm{HO}$ of $R$. calcarata for the boundary based on an informal correlation between Campanian-Maastrichtian boundary at 71.6-0.7 Ma and the base of $\mathrm{C} 32 \mathrm{~N}$ at $71.3-0.7$ Ma. It was accepted by subsequent biostratigraphic studies (Robaszynski et al., 2000; Premoli Silva \& Verga, 2004). This interval corresponds to the upper Globotruncana aegyptiaca Zone near the first appearance of the planktic foraminifera Rugoglobigerina hexacamerata and Planoglobulina carseyae, which subdivide this zone into two subzones CF8a, and CF8b (Li \& Keller, 1998a,b). Later, Li et al. (1999) used the planktic foraminiferal datum of $R$. hexacamerata at $71 \mathrm{Ma}$ for the boundary. That means the $R$. calcarata TRZ does not correspond exactly to the uppermost part of the Campanian. Also, the recent works (Georgescu \& Huber, 2007; AlMutwali et al., 2008) show that clearly.

Despite some workers (Premoli Silva \& Sliter, 1995; Nederbragt, 1991; Arz \& Molina, 2001; Ion \& Odin, 2001; Odin et al. , 2001; Premoli Silva \& Verga, 2004) who believe that the LO of Rugoglobigerina hexacamerata is older than $\mathrm{C} / \mathrm{M}$ boundary and/or this taxon shows diachronity (Arz \& Molina, 2001), here, based on Li et al. (1999), the LO of $R$. hexacamerata at distance $105 \mathrm{~m}$ from the base of the section is used for the Campanian-Maastrichtian boundary (Figure 4). This is because of the presence of Globotruncanella havanensis PRZ, Globotruncana aegyptiaca IZ, and the LO of Gansserina gansseri below the LO of $R$. hexacamerata in the studied section. It reveals that the $R$. calcarata TRZ corresponds to the early late Campanian (Figure 4).

\section{The early-late Maastrichtian boundary}

Planktonic foraminiferal workers have generally placed the early-late Maastrichtian boundary at the LO of Abathomphalus mayaroensis or Racemiguembelina fructicosa (Robaszynski et al., 1984; Boersma, 1984; Caron, 1985; Nederbragt, 1991; Li \& Keller, 1998a,b). However, A. mayaroensis is a poor biostratigraphic marker because of its diachronity (Keller, 1989b; Huber, 1990; Pardo et al., 1996), its much earlier appearance in high latitudes, and rareness or absence in neritic environments. Gradstein et al. (1995) proposed that the early-late Maastrichtian boundary to be placed at $69.5 \mathrm{Ma}$ within the upper part of C31R. This interval corresponds to the first appearance of Rosita contusa at DSDP Site 525 which marks the base of Zone CF6 (Li \& Keller, 1998a). Other works such as Li \& Keller, 1999; Li et al., 1999; Nishi et al., 2003 proposed this boundary at the LO of R. fructicosa. In contrast, Bralower et al. (1995) proposed that this boundary to be placed at the base of C30N, which corresponds to the middle of Zone CF4 (R. fructicosa Zone) at about 67.6 Ma (Figure 4). After that Permoli Silva \& Verga (2004) determined the boundary in the middle of Contusotruncana contusa-Racemiguembelina fructicosa zone. Finally, Chacon et al. (2004) and Perez-Rodriguez et al. (2012) proposed it at the LO of C. contusa. In this study, authors used the LO of C. contusa at distance $189 \mathrm{~m}$ (Figure 4) from the base of the section to approximate the early-late Maastrichtian boundary based on Chacon et al. (2004).

\section{The Cretaceous-Paleogene boundary (K/Pg)}

The Cretaceous/Paleogene boundary is placed at the base of a clay layer at the El Kef boundary stratotype section, where the boundary is recognized by a thin red oxidized layer, Ir anomaly, increasing $\mathrm{Ni}$ and total organic carbon (TOC), and the first appearance of the Paleogene planktonic foraminifera (Keller \& Lindinger, 1989; Keller et al., 1995; Li et al., 1999; Keller, 2004). The K/Pg boundary mass extinction model in planktonic foraminifera and its interpretation has been a very controversial topic. This boundary has been placed, either at the first occurrence of Paleocene species (e.g. Keller, 1989a), or at the mass extinction of Cretaceous species (e.g. Berggren \& Miller, 1988). Most of the large, ornate species disappear at or near the K/Pg boundary (Keller, 1988, 1989a,b; Keller \& MacLeod, 1994; Keller et al., 1995; Molina et al., 1996).

In the lowermost Danian sediments of the Gurpi Formation in the section studied, clays and mineral oxides are abundant but there is no major sedimentological evidence of reworking by currents or bioturbation. At the K/Pg boundary, sediments grade into gray clays with drop sharply in species reachness (extinction of calcareous planktonic groups) and carbonate content unlike siliciclastics, total organic carbon (TOC), $\mathrm{Ni}$, and Ir anomaly increasing (Figure 4). The K/Pg transition in the section is relatively expanded with a good faunal record. It shows similar faunal composition and a comparable decline but some differences exist in species of supposed survivors and the level of their last occurrences. Detailed species distribution changes (Figure 5) reveal that 20 species, or 54\%, of the late Maastrichtian species (dominantly all ornate large tropical and subtropical species including globotruncanids, racemiguemblinids, and rogoglobigerinids) disappeared at or below the $\mathrm{K} / \mathrm{Pg}$ boundary. Most of the survivor taxa are biserial (mostly heterohelicids), triserial (guembelitrids), trochospiral (hedbergellids) and planispiral (globigerinellids) in the section. These taxa are generally small with little or no surface ornamentation representing special ecological conditions. For instance, the triserial Guembelitria species are generally present in very low abundances in low to middle latitudes in Cretaceous faunal assemblages of normal open marine conditions and dominated the faunal assemblages 


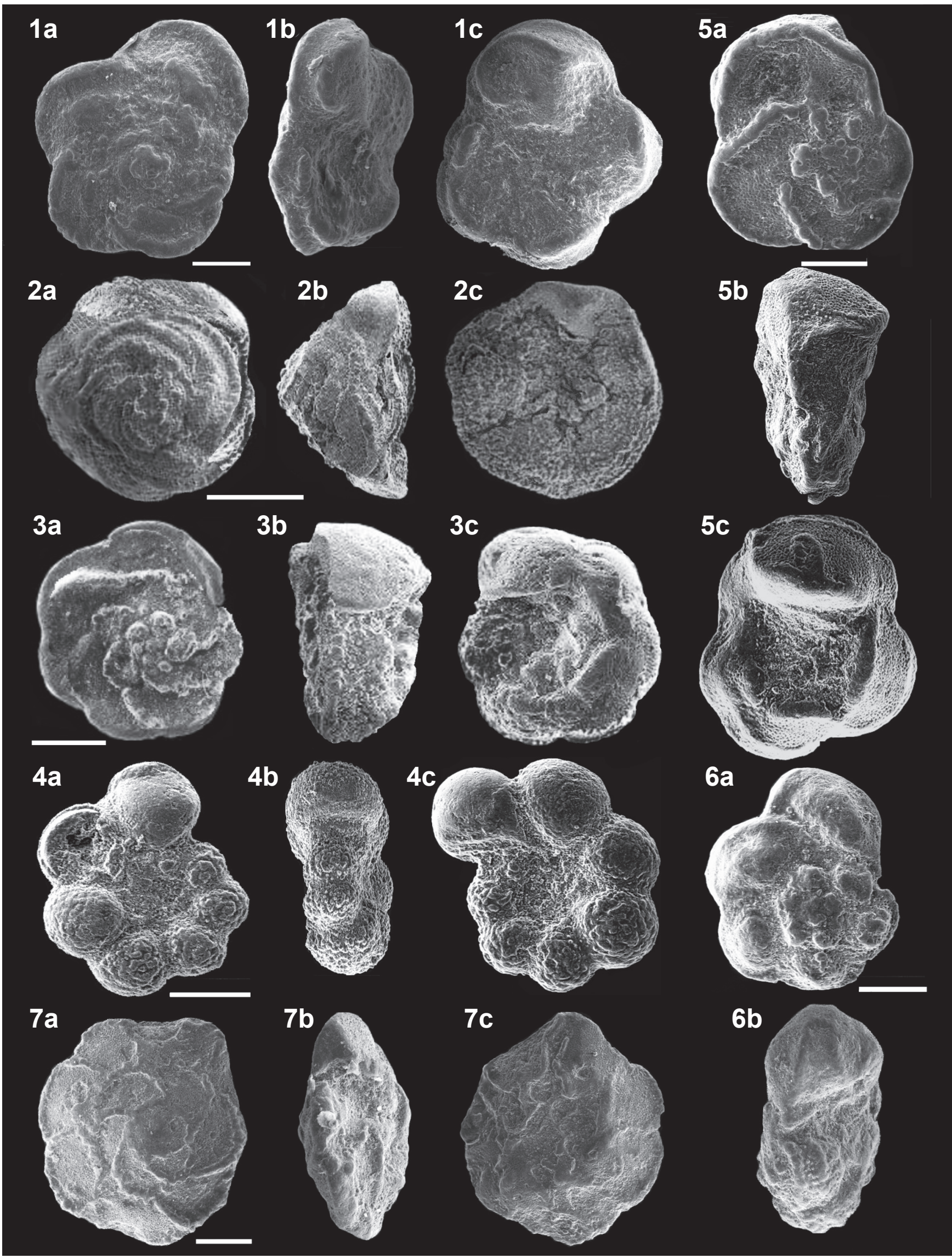

Figure 6. 1a-c, Abathomphalus mayaroensis (Bolli), S-92; 2a-c, Contusotruncana contusa (Cushman), S-72; 3a-c, Gansserina gansseri (Bolli), S-40; 4a-c, Globigerinelloides alvarezi (Eterod Olvera), S-19; 5a-c, Globotruncana aegyptiaca (Nakkady), S-19; 6a-b, Globotruncana bulloides (Vogler), S-5; 7a-c, Globotruncana dupeublei (Caron, Gonzalez Donoso, Robaszynski \& Wonders), S-30. Scale bars $=100 \mu \mathrm{m}$. 


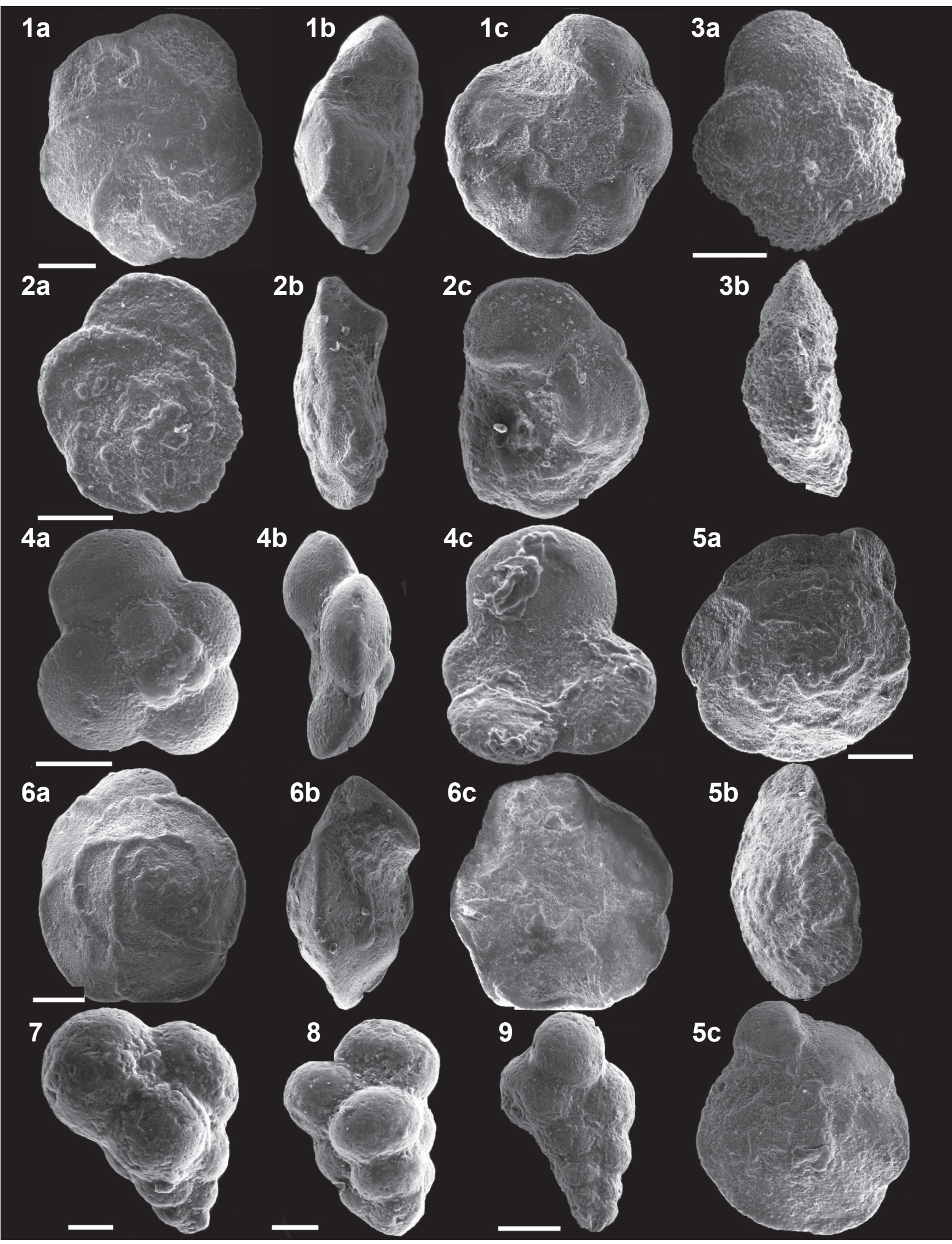

Figure 7. 1a-c, Globotruncana esnehensis (Nakkady), S-51; 2a-c, Globotruncana mariei (Banner and Blow), S-19; 3a-b, Globotruncanella havanensis (Voorwijk), S-3; 4a-c, Globotruncanella petaloidea (Gandolfi), S-39; 5a-c, Globotruncanita conica (White), S-72; 6a-c, Globotruncanita stuarti (de Lapparent), S-68; 7, Guembelitria cretacea (Cushman), S-19; 8, Guembelitria cf. danica (Hofker), S-114; 9, Guembelitria danica (Hofker), S-116. Scale bars $=100 \mu \mathrm{m}$. 


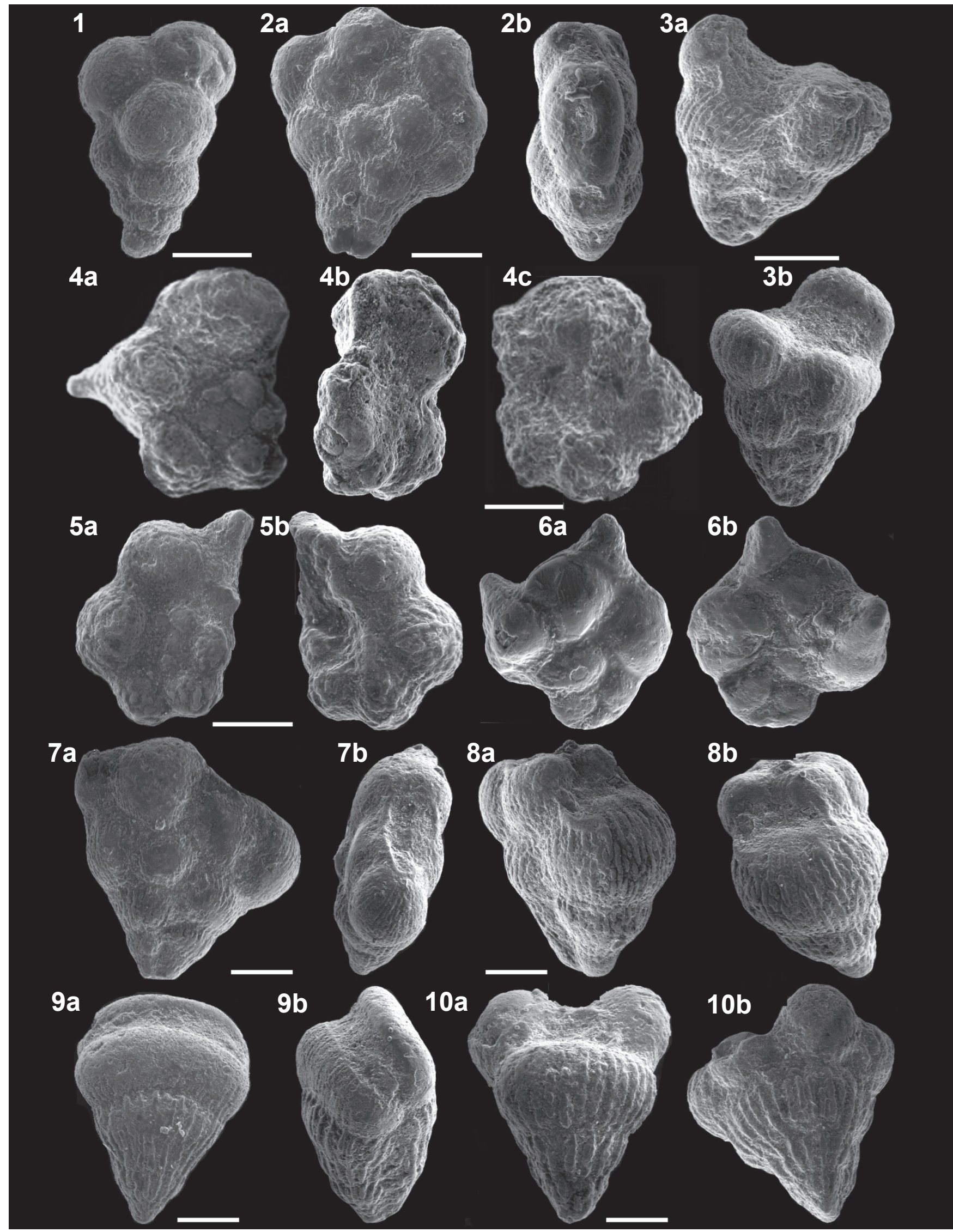

Figure 8. 1, Guembelitria irregularis (Morozova), S-116; 2a-b, Planoglobulina brazoensis (Martin), S-111; 3a-b, Planoglobulina carseyae (Plummer), S-113; 4a-c, Plummerita cf. hantkeninoides (Bronnimann), S-115; 5a-b, Plummerita cf. reicheli (Bronnimann), S-114; 6a-b, Plummerita cf. reicheli (Bronnimann), S-115; 7a-b, Pseudoguembelina brazoensis (Martin), S-94; 8a-b, Pseudoguembelina palpebra (Brönnimann \& Brown), S-106 9a-b, Pseudotextularia elegans (Rzehak), S-112; 10a-b, Pseudotextularia intermedia (De Klasz), S-84. Scale bars $=100 \mu \mathrm{m}$. 

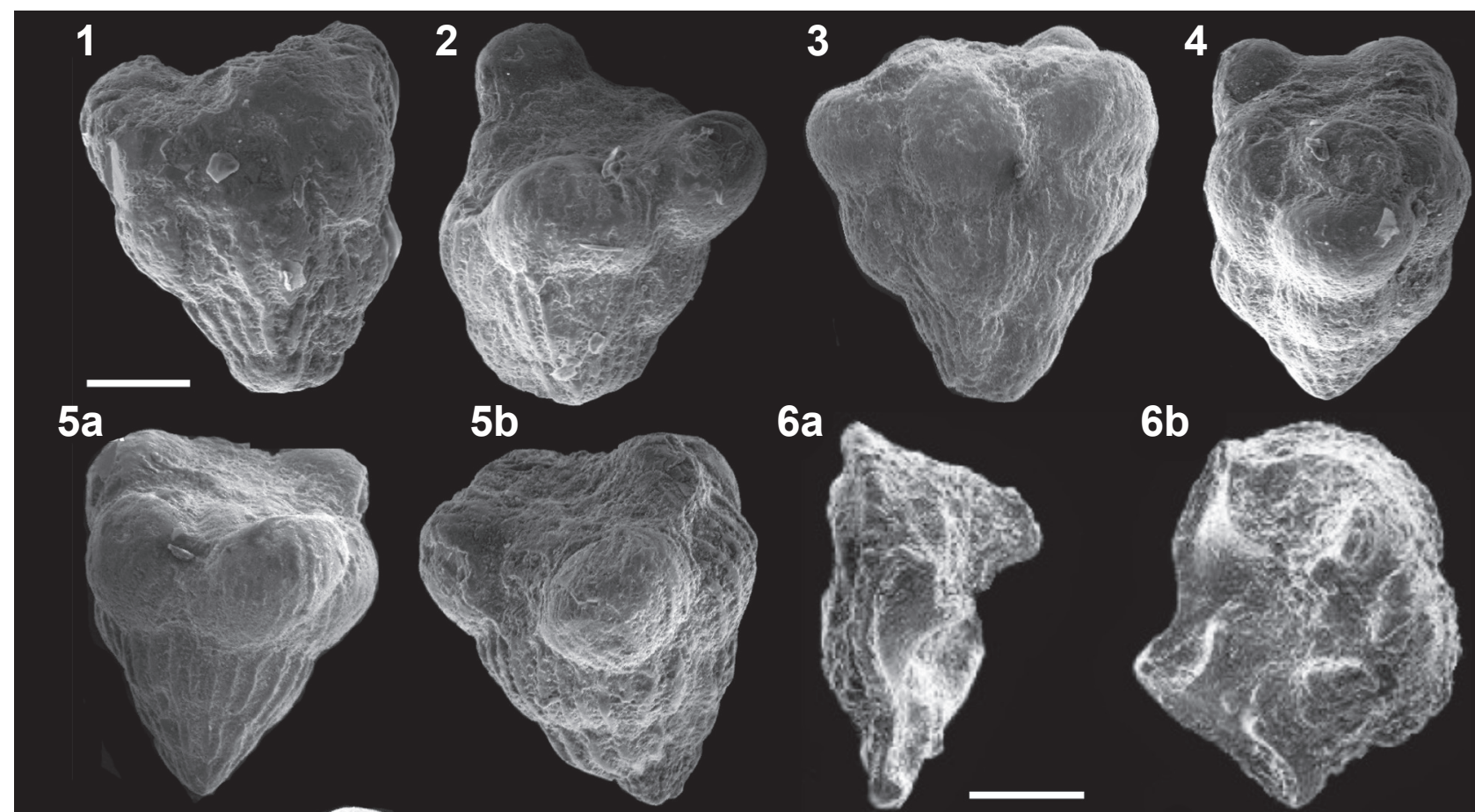

$6 \mathbf{a}$
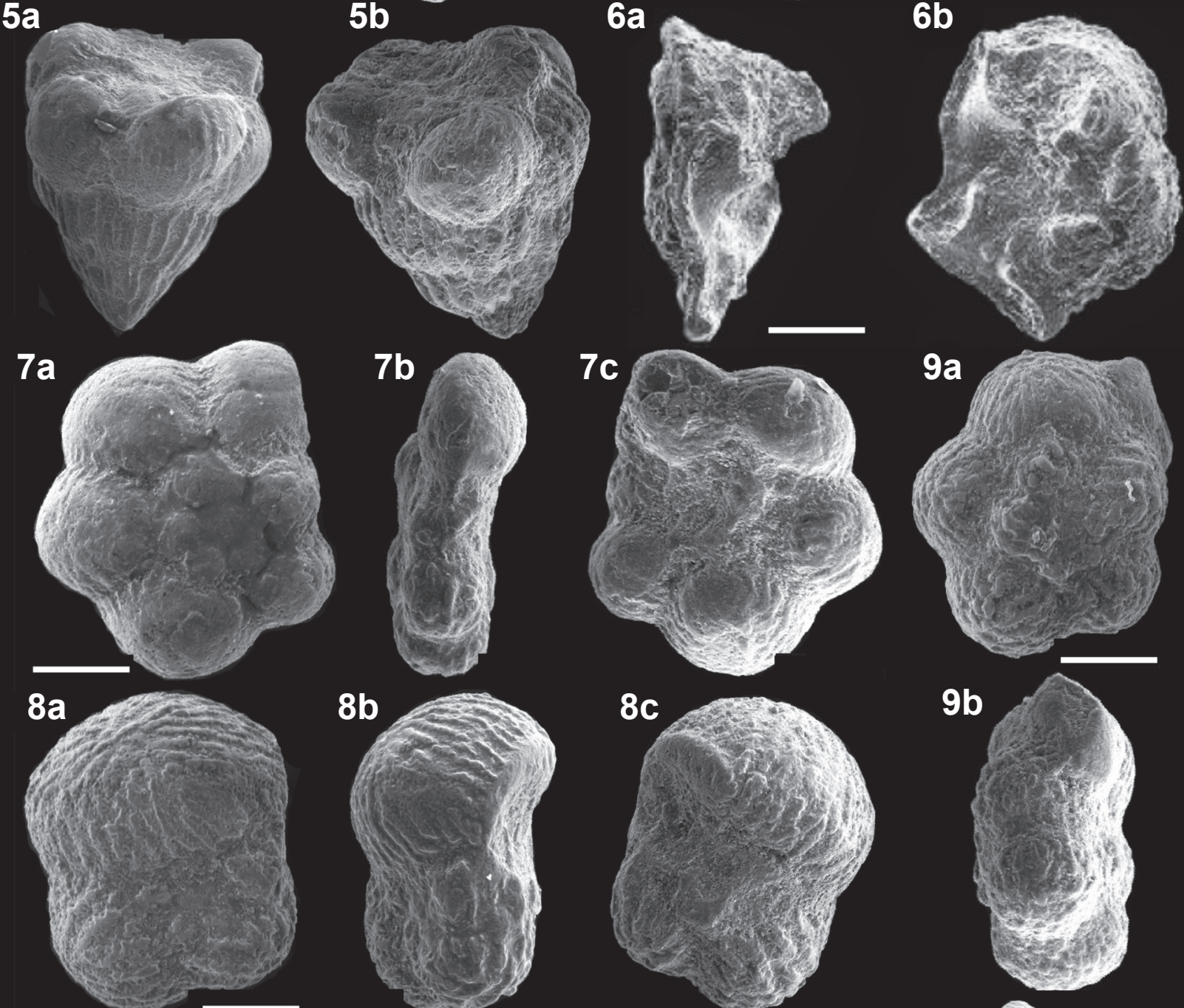

8b
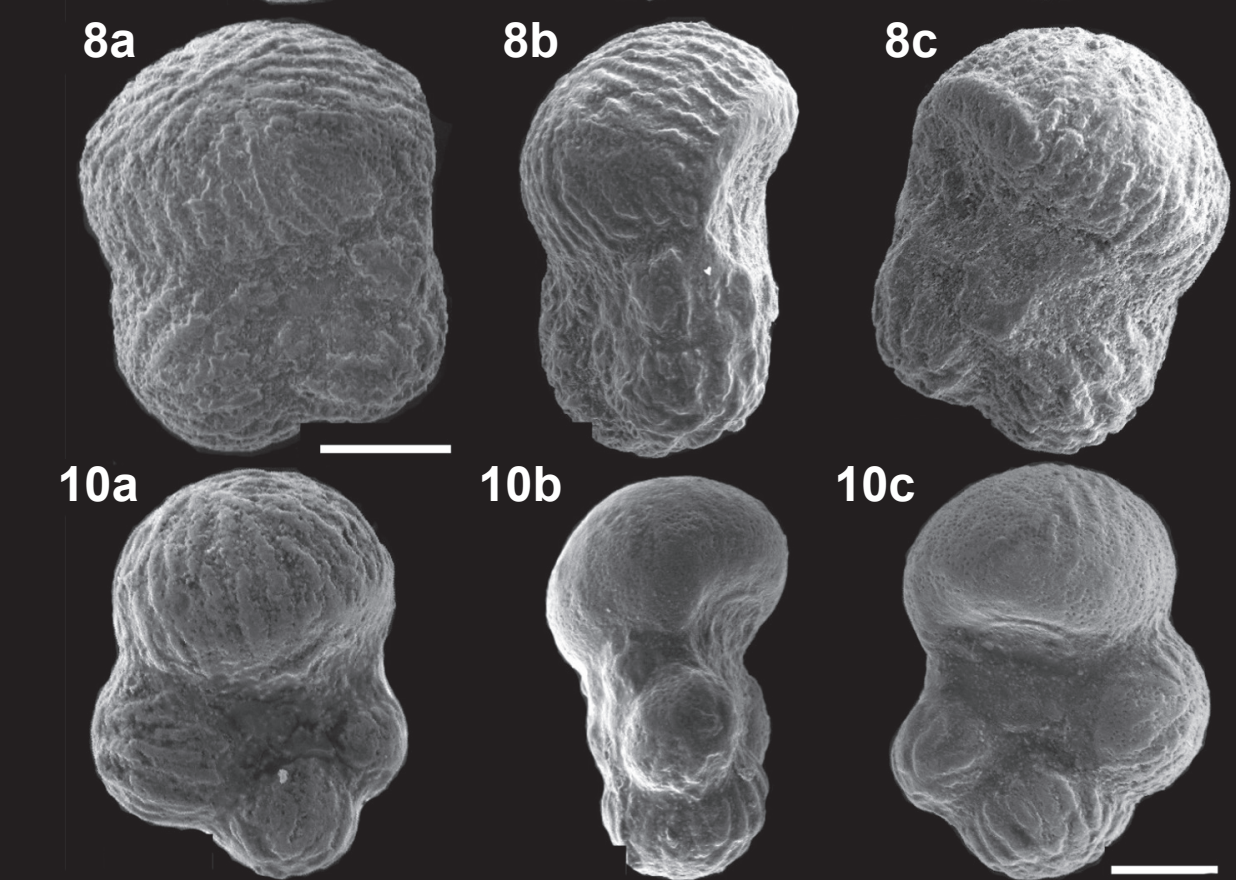
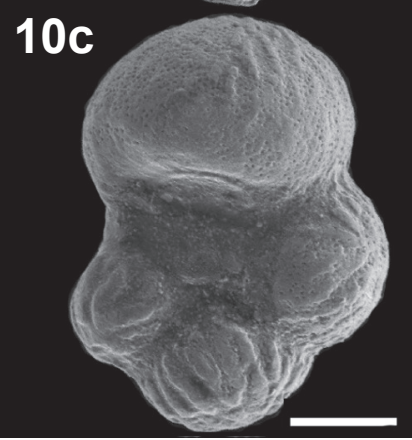

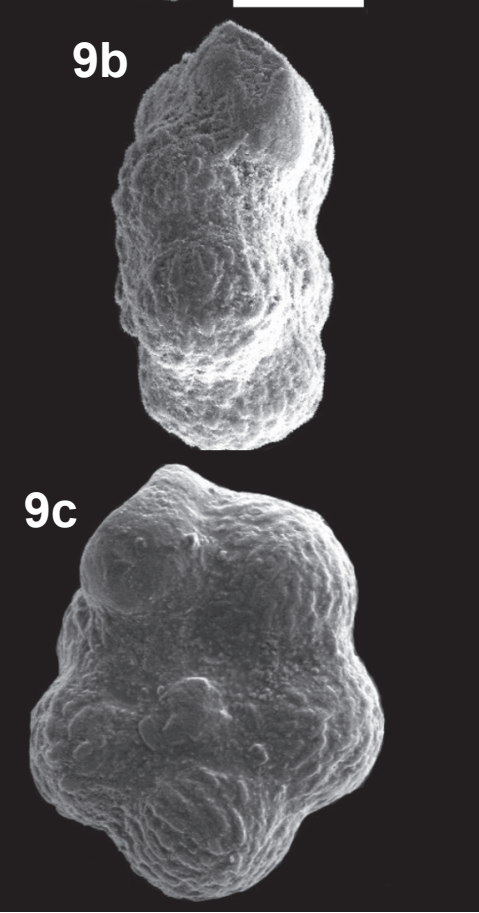

Figure 9. 1-4, Racemiguembelina fructicosa (Egger), S-87; 5a-b, Racemiguembelina powelli (Smith \& Pessagno), S-111; 6a-b, Radotruncana calcarata (Cushman) 1927, S-2; 7a-c, Rugoglobigerina hexacamerata (Brönnimann), S-42; 8a-c, Rugoglobigerina macrocephala (Brönnimann), S-42; 9a-c, Rugoglobigerina milamensis (Smith \& Pessagno), S-47; 10a-c, Rugoglobigerina rugosa (Plummer), S-9. Scale bars $=\mu \mathrm{m}$. 


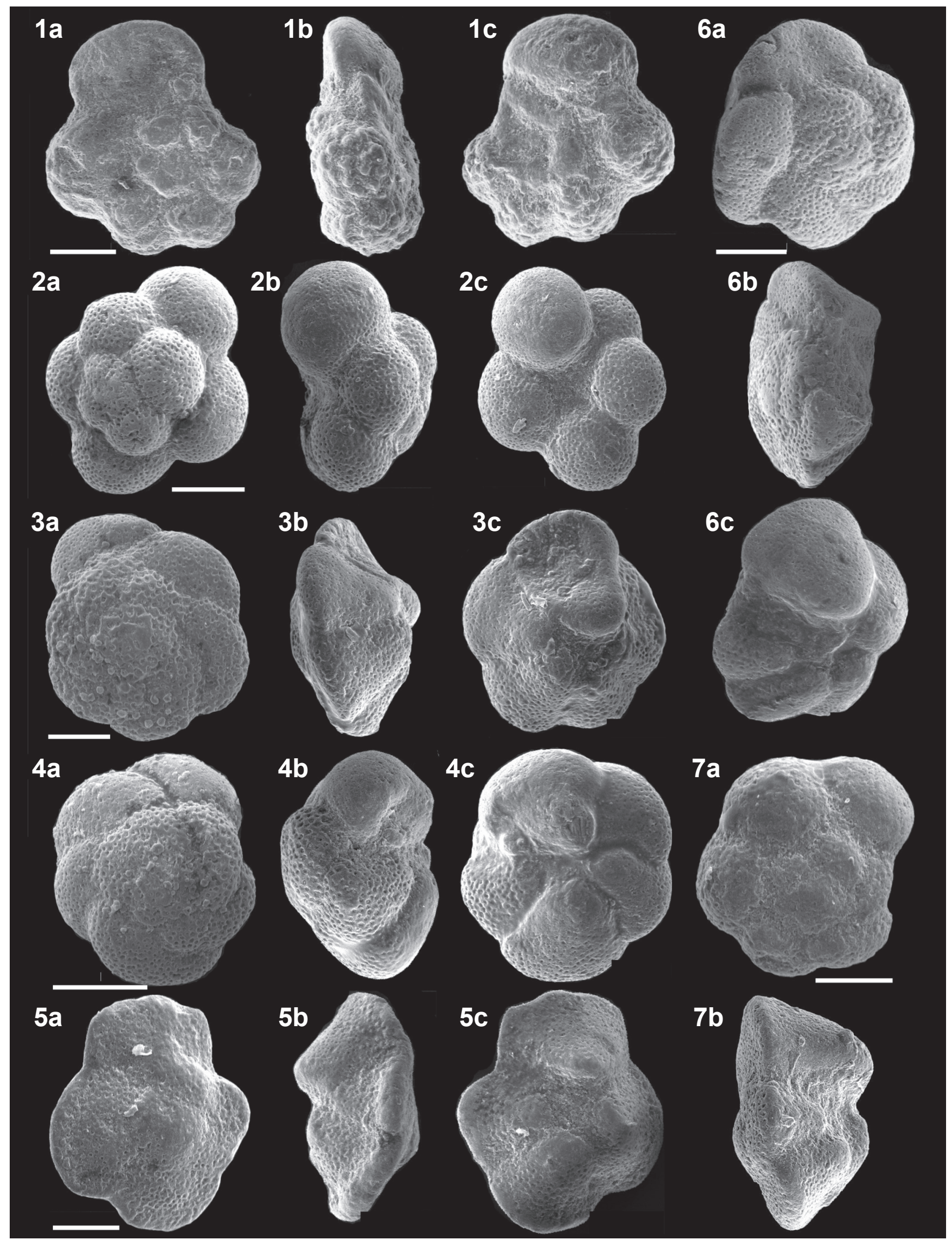

Figure 10. 1a-c, Trinitella scotti (Brönnimann), S-92; 2a-c, Eoglobigerina edita (Subbotina), S-137; 3a-c, Igorina pusilla (Bolli), S-142; 4a-c, Igorina cf. tadjikistanensis (Bykova), S-139; 5a-c, Morozovella acutispira (Bolli \& Cita), S-147; 6a-c, Morozovella angulata (White), S-140; 7a-b, Morozovella apanthesma (Loeblich \& Tappan) 1957, S-143. Scale bars $=100 \mu \mathrm{m}$. 


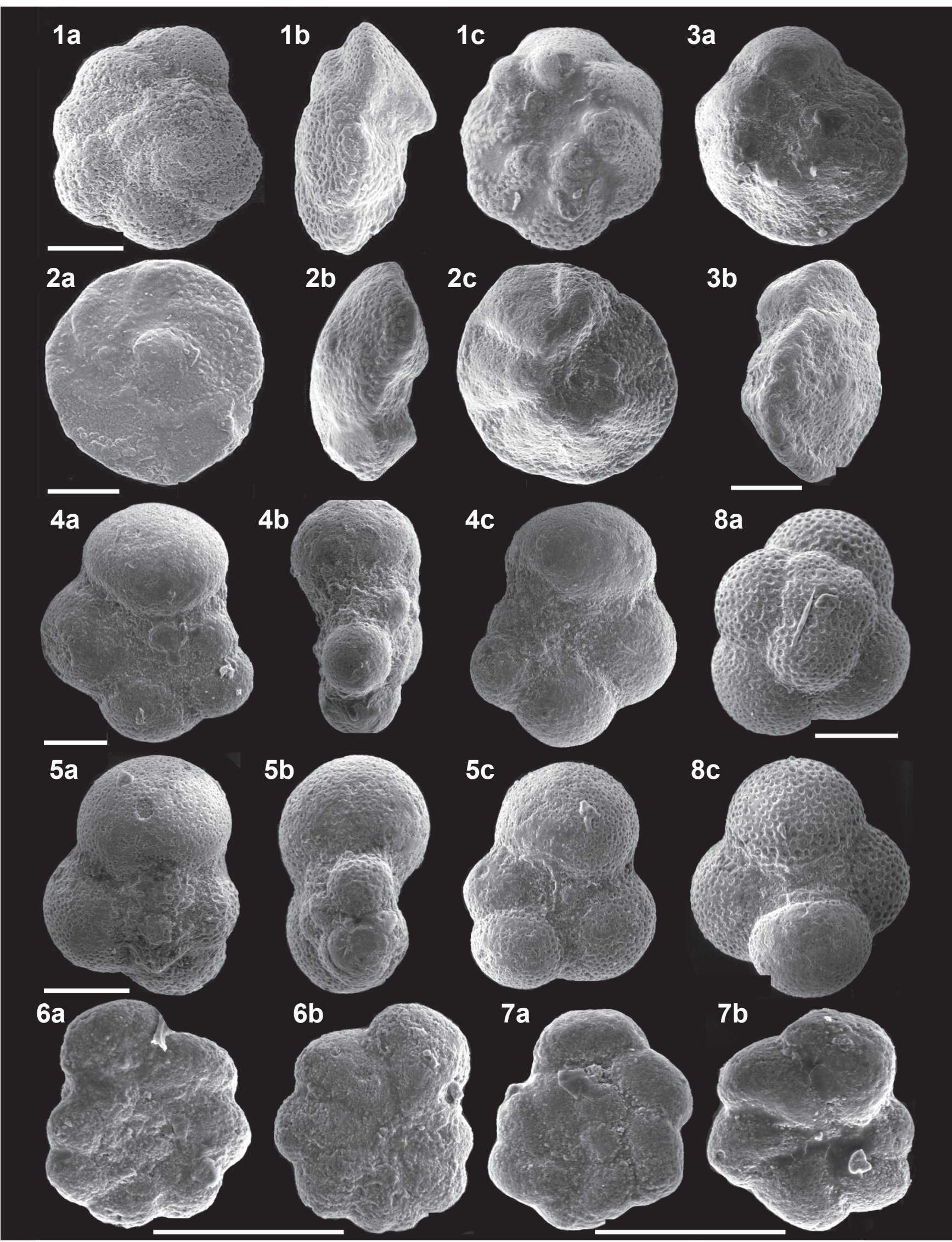

Figure 11. 1a-c, Morozovella conicotruncana (Subbotina), S-139; 2a-c, Morozovella occlusa (Loeblich \& Tappan), S-147; 3a-b, Morozovella velascoensis (Cushman), S-145; 4a-c, Parasubbotina pseudobulloides (Plummer), S-120; 5a-c, Parasubbotina varianta (Subbotina), S-127; 6a-b, Parvularugoglobigerina eugubina (Luterbacher \& Premoli Silva), S-116; 7a-b, Parvularugoglobigerina longiapertura (Blow), S-116; 8a-c, Subbotina trivialis (Subbotina), S-116. Scale bars $=100 \mu \mathrm{m}$. 


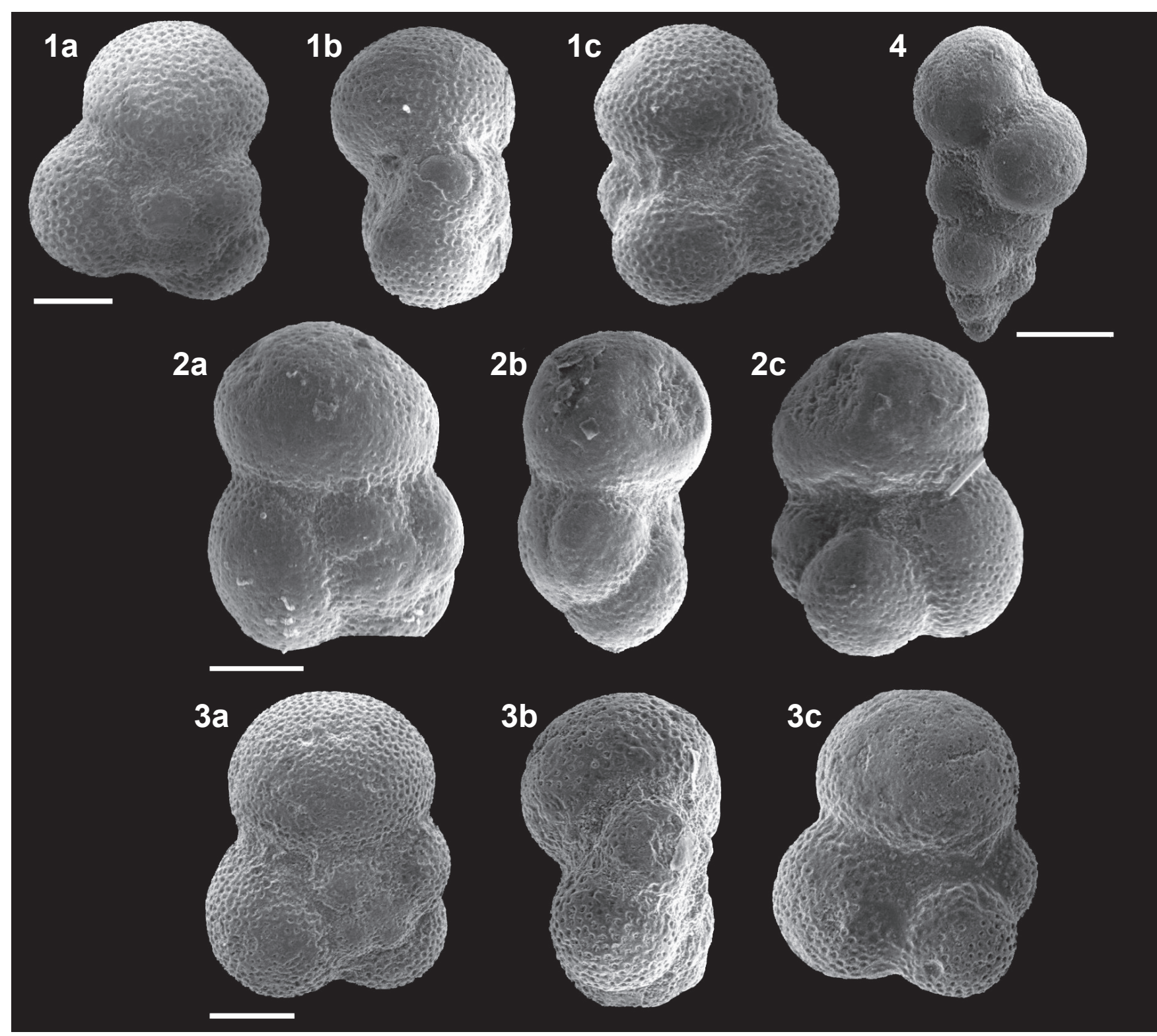

Figure 12. 1a-c, Subbotina cancellata (Blow), S-136; 2a-c, Subbotina triangularis (White), S-135; 3a-c, Subbotina triloculinoides (Plummer), S-128; 4, Woodringina hornerstownensis (Olsson), S-116. Scale bars $=100 \mu \mathrm{m}$.

in shallow neritic near-shore environments during the early Danian (Keller et al., 1998).

This extinction pattern at the studied section is similar to those observed in other tropical-subtropical, El Kef and Elles (Keller, 1988; Keller et al., 1995, 2002; Molina et al., 1998, 2006; Karoui-Yakoub et al., 2002), and low latitude (Luciani, 2002; Canudo et al., 1991; Keller, 1989a,b; Keller et al., 1994; Lopez-Oliva \& Keller, 1996) K/Pg boundary successions. Variations in the extinction pattern are primarily due to differential preservation, analytical methods used (e.g. size fraction analyzed and sample intervals) and local environmental conditions. Based on the biozonation of Keller et al. (1995), presence of the main species of the Guembelitria group (G. cretacea, G. irregularis, and G. trifolia) simultaneously with absence of Plummerita hantkeninoides, Parvularugoglobigerina eugubina, Pv. longiappetura, Eoglobigerina fringe, and E. eobulloides is the best method to identify the basal Danian organic rich black clay layer of P0 biozone in the studied section (Figure 5).

\section{DISCUSSION AND CONCLUSIONS}

The present study is a biostratigraphic analysis of the Gurpi Formation (late Campanian-Selandian) in Izeh Zone, the Zagros Basin, southwest of Iran with attention to the $\mathrm{K}$ Pg boundary. Distribution of the identified species based on the planktonic foraminiferal zonal schemes established for the Tethyan Realm, was the main basis for the biostratigraphic studies.

Radotruncana calcarata TRZ (10 m thick, early late Campanian), Globotruncanella havanensis PRZ (40 m thick, late Campanian), Globotruncana aegyptiaca IZ (30 $\mathrm{m}$ thick, late Campanian), and lower part of the Gansserina gansseri IZ (25 m thick, latest Campanian) belong to the late 
Campanian. In this investigation, the LO of Rugoglobigerina hexacamerata was used for the Campanian-Maastrichtian boundary (Figure 4).

The early-late Maastrichtian boundary is defined here based on the lowest occurrence of Contusotruncana contusa. Unlike the early Maastrichtian period that is defined only by the Gansserina gansseri IZ, the late Maastrichtian comprises many zones and subzones. It consists of C. contusa IZ $(30 \mathrm{~m}$ thick, early late Maastrichtian), Abathomphalus mayaroensis TRZ (53 m thick, late Maastrichtian) and four subzones of CF4, CF3, CF2 and CF1.

Although it has been confirmed that a hiatus occurs in most $\mathrm{K} / \mathrm{Pg}$ sections in southwest Iran (James \& Wynd, 1965; Wynd, 1965; Sampo, 1969; Setudehnia 1972, 1978; Motiei, 2003; Ghasemi-Nejad et al., 2006), the planktonic foraminiferal analysis of the $\mathrm{K} / \mathrm{Pg}$ transition in the studied section indicates that the boundary is continuous. Because of this, the controversy over the change in the planktonic foraminiferal fauna across the $\mathrm{K} / \mathrm{Pg}$ boundary is one of the main objects of the discussion. Although the larger, more ornate Cretaceous species disappear below the boundary in common with most continuous $\mathrm{K} / \mathrm{Pg}$ sections around the world, but some keeled forms (e.g. Globotruncana aegyptiaca and Globotruncanita stuarti) have also been recorded in the base of the Paleocene strata that are considered as reworked or dwarfed and simpler than their Cretaceous counterparts. However, a large number of simple, small, unkeeled Cretaceous specimens ( $46 \%$ of the total population) occur in the early Paleocene sediments of the section. The gradual extinction of many Cretaceous species in the lowermost Paleocene seems to characterize most of the continuous $\mathrm{K} / \mathrm{Pg}$ boundary successions, demonstrating the great complexity of this transition, which involves various environmental changes.

The Paleocene improved bioevents of the section seem to be more useful for the subdivisions of the Danian and Selandian stages than the available zonal schemes. Guembelitria cretacea PRZ, P0 (23 cm thick, early Danian), Parvularugoglobigerina eugubina PRZ, Pa (100 cm thick, early Danian), Parvularugoglobigerina eugubina-Subbotina triloculinoides Zone, P1 (27 m thick, early Danian) that consists of three biostratigraphic subzones [Parasubbotina pseudobulloides PRSZ (P1a), Subbotina triloculinoides LOSZ (P1b), and Globanomalina compressa-Praemurica uncinata LOSZ (P1c)], Praemurica uncinata LOZ, P2 (11 m thick, Late Danian), and Morozovella angulata LOZ, P3 (23 m thick, Selandian) are proposed as constituent biostratigraphic subdivisions of the Paleocene time interval. The last biozone comprises two subzones of Igorina pusilla PRSZ (P3a) and Igorina albeari LOSZ (P3b).

The early late Campanian rocks contain Radotruncana calcarata at the base of the Gurpi Formation represent a remarkable sequence that disconformably overlie the Ilam Formation. Based on the microfacies evidences of the sediments (Figure 4), the late Campanian-early Maastrichtian succession (Lower Gurpi Formation) is interpreted as representing outer shelf deposition, Emam Hassan Member records a regressive-transgressive pulse within a shelf setting (outer shelf and possibly mid to inner shelf settings during regression), and the succession ended (upper Gurpi formation) with sedimentation in a deeper marine environment of outer shelf (Hemmati-Nasab et al., 2008). It seams that the section studied can be corresponded with the middle and outer shelf Tunisian K/Pg section at El Kef (Keller et al., 2002).

In addition to biostratigraphic events, some direct physical evidence (e.g. changes in minor and trace elements like Ir and $\mathrm{Ni}$, spectrometry gamma ray, total organic carbon, quartz, and calcite components) in pelagic marine sequences where nearly continuous deposition is to be expected, commonly mark the $\mathrm{K} / \mathrm{Pg}$ boundary (Alvarez et al., 1980; Keller \& Stinnesbeck, 2000; Luciani, 2002). Here, similar data is presented for an unusual event at exactly the time of the extinctions in the planktonic realm. There is a good correlation between the species richness, biostratigraphic events and direct physical evidence at the $\mathrm{K} / \mathrm{Pg}$ boundary in the section studied (Figure 4). All the data are presented here in percentage.

\section{ACKNOWLEDGMENTS}

The authors thank G. Keller (Princeton University) for her careful review and many constructive remarks that greatly improved quality of this paper. M.R. Kamali and S.S. Hendi, head of Exploration Research and Development Department of RIPI, are acknowledged for their support. This research was funded by Research Institute of Petroleum Industry (RIPI) of Iran.

\section{REFERENCES}

Ala, M.A.; Kinghorn, R.R.F. \& Rahman, M. 1980. Organic geochemistry and source rock characteristics of the Zagros Petroleum province, southwest Iran. Journal of Petroleum Geology, 3:61-89.

Alavi, M. 2004. Regional stratigraphy of the Zagros fold-thrust belt of Iran and its proforeland evolution. American Journal of Science, 304:1-20.

Alvarez, L.W.; Alvarez, W.; Asaro, F. \& Michel, H.V. 1980. Extraterrestrial cause for the Cretaceous-Tertiary extinction. Science, 208:1095-1108.

Almogi-Labin, A.; Reiss, Z. \& Caron, M. 1986. Senonian Globotruncanidae from Israel. Eclogae Geologicae Helvetiae, 79:849-895.

Al-mutwali, M.M.; Al-banna, N.Y. \& Al-ghrear, J.S. 2008. Microfacies and sequence stratigraphy of the Late Campanian Bekhme Formation in the Dohuk area, north Iraq. GeoArabia, 13:39-54.

Arenillas, I.; Arz, J.A. \& Molina, E. 2004. A new high-res olution planktic foraminiferal zonation and subzonation for the lower Danian. Lethaia, 37:79-95.

Arz, J.A. \& Molina, E. 2001. Planktic foraminiferal quantitative analysis across the Campanian/Maastrichtian boundary at Tercis (Landes, France). In: G.S. Odin (ed.) The CampanianMaastrichtian stage boundary: characterisation at Tercis les Bains (France) and correlation with Europe and other continents, Amsterdam, Elsevier, p. 338-348 (Developments in Palaeontology and Stratigraphy 19).

Berggren, W.A.; Aubry, M.P.; Van Fossen, M.; Kent, D.V.; Noriris, R.D. \& Quille've're', F. 2000. Integrated Paleocene calcareous 
plankton magnetobiochronology and stable isotope stratigraphy: DSDP Site 384 (NWAtlantic Ocean). Palaeogeography, Palaeoclimatology, Palaeoecology, 159:1-51.

Berggren, W.A.; Kent, D.V.; Swisher, C.C. \& Aubrey, M.P. 1995. A revised Cenozoic geochronology and chronostratigraphy. In: W.A. Berggren; D.V. Kent; C.C. Swisher III, M.-P. Aubry \& J. Hardenbol (eds.) Geochronology, Time Scales and Global Stratigraphic Correlation, Tulsa, SEPM, p. 129-212 (Special Publication 54).

Berggren, W.A. \& Miller, K.G. 1988. Paleocene tropical planktonic foraminiferal biostratigraphy and magnetobiochronology. Micropaleontology, 34:362-380.

Berggren, W.A. \& Pearson, P.N. 2005. A revised tropical to subtropical Paleogene planktonic foraminiferal zonation. Journal of Foraminiferal Research, 35:279-298.

Bolli, H.M. 1957. Planktonic foraminifera from the Eocene Navet Formation and San Fernando Formations in Trinidad, B.W.I. Bulletin of the United States National Museum, 215:155-172.

Boersma, A. 1984. Handbook of common Tertiary Uvigerina. New York, Microclimates Press, 207 p.

Bralower, T.J.; Zachos, J.C.; Thomas, E.; Parrow, M.; Paull, C.K.; Kelly, D.C.; Premoli Silva, I.; Sliter, W.V. \& Lohmann, K.C. 1995. Late Paleocene to Eocene paleoceanography of the equatorial Pacific Ocean: stable isotopes recorded at ODP Site 865, Allison Guyot. Paleoceanography, 10:841-865.

Canudo, J.I.; Keller, G. \& Molina, E. 1991. Cretaceous/Tertiary boundary extinction pattern and faunal turnover at Agost and Caravaca, SE Spain. Marine Micropaleontology, 17:319-341.

Caron, M. 1978. Cretaceous planktonic foraminifers from DSDP Leg 40, Southeastern Atlantic Ocean. Initial Reports of Deep Sea Drilling Project, 40:651-678.

Caron, M. 1985. Cretaceous planktic foraminifera. In: H.M. Bolli; J.B. Saunders \& K. Perch- Nielsen (eds.) Plankton Stratigraphy, Cambridge University Press, p. 11-86.

Chacón, B.; Martíne Chivelet, J. \& Gräfe, K.U. 2004. Latest Santonian to latest Maastrichtian planktic foraminifera and biostratigraphy of the hemipelagic successions of the Prebetic Zone (Murcia and Alicante provinces, south-east Spain). Cretaceous Research, 25:585-601.

Darvishzad, B.; Ghasemi-Nejad, E.; Ghourchaei, S. \& Keller, G. 2007. Planktonic foraminiferal biostratigraphy and faunal turnover across the $\mathrm{K} / \mathrm{Pg}$ boundary in southwestern Iran. Journal of Sciences, Islamic Republic of Iran, 18:139-149.

D'Hondt, S. \& Keller, G. 1991. Some patterns of planktic foraminiferal assemblage turnover at the Cretaceous-Tertiary boundary. Marine Micropaleontology, 17:77-118.

Gallala, N. \& Zaghbib-Turki, D. 2010. High resolution biostratigraphy based on planktonic foraminifera across the Cretaceous/ Paleogene (K/Pg) transition at the Bidart section (SW France). Acta Geologica Polonica, 60:243-255.

Gallala, N.; Zaghbib-Turki, D.; Arenillas, I.; Arz J.A. \& Molina, E. 2009. Catastrophic mass extinction and assemblage evolution in planktic foraminifera across the Cretaceous/Pale- ogene (K/ $\mathrm{Pg}$ ) boundary at Bidart (SW France). Marine Micropaleontology, 72:196-209.

Gealey, W.K. 1988. Plate tectonic evolution of the MediterraneanMiddle East Region. Tectonophysics, 155:285-306.

Georgescu, M.D. \& Huber, B.T. 2007. Taxonomic revision of the late Campanian-Maastrichtian (Late Cretaceous) planktonic foraminiferal genus Rugotruncana Bronnimann and Brown, 1956, and a new paleontological species concept for planktonic foraminifera. Journal of Foraminiferal Research, 37:58-67.
Ghasemi-Nejad, E.; Hobbi M.H. \& Schiøler, P. 2006. Dinoflagellate and foraminiferal biostratigraphy of the Gurpi Formation (upper Santonian-upper Maastrichtian), Zagros Mountains, Iran. Cretaceous Research, 27:828-835

Gradstein, F.M.; Agterberg, F.P.; Ogg, J.G.; Hardenbol, J.; van Veen, P.; Thierry, J. \& Huang, Z. 1995. A Triassic, Jurassic and Cretaceous time scale. In: W. A. Berggren; D. V. Kent; C. C. Swisher III, M.-P. Aubry \& J. Hardenbol (eds.) Geochronology, Time Scales and Global Stratigraphic Correlation, Tulsa, SEPM, p. 95-126 (Special Publication 54).

Haq, B.U.; Hardenbol, J. \& Vail, P.R. 1987. Chronology of fluctuating sea levels since the Triassic. Science, 235:1156-1166.

Hemmati-Nasab, M.; Ghasemi-Nejad, E. \& Darvishzad, B. 2008. Paleobathymetry of the Gurpi Formation based on benthic and planktonic foraminifera in Southwestern Iran. Journal of Sciences, Islamic Republic of Iran, 34:157-173.

Huber, B.T. 1990. Maestrichtian planktonic foraminifer biostratigraphy of the Maud Rise (Weddell Sea, Antarctica): ODP Leg 113 Holes 689B and 690C. In: P.F. Barker et al. (eds.) Proceedings ODP Science Results, 113:489-513.

Ion, J. \& Odin, G.S. 2001. Planktonic foraminifera from the Campanian-Maastrichtian at Tercis les Bains (Landes, France). In: G.S. Odin (ed.) The Campanian-Maastrichtian stage boundary: characterisation at Tercis les Bains (France) and correlation with Europe and other continents, Amsterdam, Elsevier, p. 349-378 (Developments in Palaeontology and Stratigraphy 19).

James, G.A. \& Wynd, J.G. 1965. Stratigraphic nomenclature of the Iranian oil consortium agreement area. Bulletin of the American Association of Petroleum Geologists, 49:2182-2245.

Karoui-Yaakoub, N.; Zaghbib-Turki, D. \& Keller, G. 2002. The Cretaceous/Tertiary (K/T) mass extinction in planktic foraminifera at Elles I and El Melah, Tunisia. Palaeogeography, Palaeoclimatology, Palaeoecology, 178:233-255.

Keller, G. 1988. Extinction, survivorship and evolution of planktic foraminifera across the Cretaceous-Teritary boundary at El Kef, Tunisia. Marine Micropaleontology, 13:239-263.

Keller, G. 1989a. Extended period of extinctions across the Cretaceous/Teriary boundary in planktonic foraminifera of continental shelf section: implications for an impact and volcanism theories. Bulletin of the Geological Society of American, 101:1408-1419.

Keller, G. 1989b. Extended Cretaceous/Teriary boundary extinctions and delayed population change in planktonic foraminifera from Brazos River, Texas. Paleoceanography, 4:287-332.

Keller, G. 2004. Low-diversity, late Maastrichtian and early Danian planktic foraminiferal assemblages of the eastern Tethys. Journal of Foraminiferal Research, 34:49-73.

Keller, G.; Adatte, T.; Stinnesbeck, W.; Luciani, V.; KarouiYaakoub, N. \& Zaghbib-Turki, D. 2002. Paleoecology of the Cretaceous-Tertiary mass extinction in planktonic foraminifera. Palaeogeography, Palaeoclimatology, Palaeoecology, 178:257297.

Keller, G. \& Lindinger, M., 1989. Stable isotopes, TOC and $\mathrm{CaCO}_{3}$ records across the Cretaceous-Tertiary boundary at El Kef, Tunisia. Palaeogeography, Palaeoclimatology, Palaeoecology, 73:243-265.

Keller, G. \& MacLeod, N. 1994. The K-T boundary transition in the Antarctic Ocean: reply. Marine Micropaleontology, 24:91-99.

Keller, G. \& Stinnesbeck, W. 2000. Iridium and the K/T boundary at El Caribe, Guatemala. International Journal of Earth Sciences, 88:840-843. 
Keller, G.; Stinnesbeck, W. \& Lopez-Oliva, J.G. 1994. Age, deposition and biotic effects of the Cretaceous/Tertiary boundary event at Mimbral, NE Mexico. Palaios, 9:144-157.

Keller, G.; Li, L. \& MacLeod, N. 1995. The Cretaceous/Tertiary boundary stratotype section at El Kef, Tunisia: how catastrophic was the mass extinction? Palaeogeography, Palaeoclimatology, Palaeoecology, 119:221-254.

Koop, W.J. \& Stoneley, R. 1982. Subsidence History of Middle East Zagros Basin, Permian to Recent. Philosophical Transactions of the Royal Society, B306:149-157.

Li, L. \& Keller, G. 1998a. Maastrichtian climate, productivity and faunal turnovers in planktic foraminifera in South Atlantic DSDP Sites 525 and 21. Marine Micropaleontology, 33:55-86.

Li, L. \& Keller, G. 1998b. Maastrichtian diversification of planktic foraminifera at El Kef and Elles, Tunisia. Eclogae Geologicae Helvetiae, 91:75-102.

Li, L. \& Keller, G. 1999. Variability in Late Cretaceous climate and deep waters: evidence from stable isotopes. Marine Geology, 161:171-190.

Li, L.; Keller, G. \& Stinnesbeck, W. 1999. The Late Campanian and Maastrichtian in northwestern Tunisia: paleoenvironmental inferences from lithology, macrofauna and benthic foraminifera. Cretaceous Research, 20:231-252.

Liu, C. \& Olsson, R.K. 1992. Evolutionary radiation of microperforate planktonic foraminifera following the $\mathrm{K} / \mathrm{T}$ mass extinction event. Journal of Foraminiferal Research, 22:328-346.

Lopez-Oliva, J.G. \& Keller, G. 1996. Age and stratigraphy of near$\mathrm{K} / \mathrm{T}$ boundary clastic deposits in NE Mexico. In: The CretaceousTertiary event and other catastrophes in Earth history, New York, Geological Society of America, p. 227-242 (Special Paper 307).

Luciani, V. 2002. High-resolution planktonic foraminiferal analysis from the Cretaceous-Tertiary boundary at Ain Settara (Tunisia): evidence of an extended mass extinction. Palaeogeography, Palaeoclimatology, Palaeoecology, 178:299-319.

Luterbacher, H.P. \& Premoli Silva, I. 1964. Biostratigrafia del limite Cretaceo-Terziario nell' Appennino centrale. Rivista Italiana di Paleontologia e Stratigrafia, 70:67-128.

Masters, B.A. 1984. Comparison of planktonic foraminifers at the Cretaceous-Tertiary boundary from the El Haria shale (Tunisia) and the Fsna shale (Egypt). In: EXPLORATION SEMINAR, 7, 1984. Proceedings, Cairo, Egyptian General Petroleum Corporation, p. 310-324.

Molina, E.; Alegret L.; Arenillas, I.; Arz, J.A.; Gallala, N.; Hardenbol, J.; Von Salis, K.; Steurbaut, E.; Vandenbeghe, N. \& ZaghbibTurki, D. 2006. The global boundary stratotype section and point for the base of the Danian stage (Paleocene, Paleogene, "Tertiary", Cenozoic) at El Kef, Tunisia: original definition and revision. Episodes, 29:263-278.

Molina, E.; Arenillas, I. \& Arz, A. 1996. The Cretaceous/Tertiary boundary mass extinction in planktonic foraminifera at Agost, Spain. Revue de Micropaléontologie, 22:225-243.

Molina, E.; Arenillas, I. \& Pardo, A. 1998. Planktonic foraminifera biostratigraphy across the Paleocene/Eocene boundary and correlations. Strata, 1:93-96.

Motiei, H. 2003. Stratigraphy of Zagros. In: Treatise on the Geology of Iran, Geological Survey of Iran, 583 p.

Murris, R.J. 1980. The Middle East stratigraphic evaluation and oil habitat. Bulletin of the American Association of Petroleum Geologists, 64:597-618.

Nederbragt, A. 1991. Late Cretaceous biostratigraphy and development of Heterohelicidae (planktic foraminifera). Micropaleontology, 37:329-372.
Nishi, H.; Takashima, R.; Hatsugai, T.; Saito, T.; Moriya, K.; Ennyu, A. \& Sakai, T. 2003. Planktonic foraminiferal zonation in the Cretaceous Yezo Group, Central Hokkaido, Japan. Journal of Asian Earth Sciences, 21:867-886.

Odin, G.S.; Arz, J.A.; Caron, M.; Ion, J. \& Molina, E. 2001. Campanian-Maastrichtian planktonic foraminifera at Tercis les Bains (Landes, France): synthetic view and potential for global correlation. In: G.S. Odin (ed.) The Campanian-Maastrichtian stage boundary: characterisation at Tercis les Bains (France) and correlation with Europe and other continents, Amsterdam, Elsevier, p. 379-395 (Developments in Palaeontology and Stratigraphy 19).

Olsson, R.K. \& collaborators 1999. Atlas of Paleocene Planktonic Foraminifera. Smithsonian Contributions to Paleobiology, 85:1-252.

Pardo, A.; Ortiz, N. \& Keller, G. 1996. Latest Maastrichtian foraminiferal turnover and its environmental implications at Agost, Spain. In: N. MacLeod \& G. Keller (eds.) CretaceousTertiary boundary mass extinction: biotic and environmental changes, W.W. Norton, p. 139-172.

Pardo, A.; Keller, G.; Molina, E. \& Canudo, J.I. 1997. Planktic foraminiferal turnover across the Paleocene-Eocene transition at DSDP Site 401, Bay of Biscay, North Atlantic. Marine Micropaleontology, 29:129-158.

Pérez-Rodríguez, I.; Lees, J.A.; Larrasoaña, J.C.; Arz, J.A. \& Arenillas, I. 2012. Planktonic foraminiferal and calcareous nannofossil biostratigraphy and magnetostrati-graphy of the uppermost Campanian and Maastrichtian at Zumaia, northern Spain. Cretaceous Research, 37:100-126.

Premoli Silva, I. \& Sliter, W.V. 1994. Cretaceous planktic foraminiferal biostratigraphy and evolutionary trends from the Bottacione section, Gubbio, Italy. Palaeontographia Italica, 82:1-89.

Premoli Silva I. \& Sliter, W.V. 1995. Cretaceous planktonic foraminiferal biostratigraphy and evolutionary trends from the Bottaccione section, Gubbio, Italy. Palaeontographia Italica, 82:1-89.

Premoli Silva, I. \& Verga, D. 2004. Practical Manual of Cretaceous Planktonic Foraminifera, Course 3. In: D. Verga \& R. Rettori (eds.) International School on Planktonic Foraminifera, Universities of Perugia and Milano, Tipografiadi di Pontefelcino, $283 \mathrm{p}$.

Robaszynski, F. \& Caron, M. 1995. Foraminifères planctoniques du Crétacé: commentaire de la zonation Europe-Mediterrane. Bulletin de la Société Géologique de France, 166:681-692.

Robaszynski, F. \& collaborators 1984. Atlas of Late Cretaceous Globotruncanids. Revue de Micropaléontologie, 26:145-305.

Robaszynski, F.; Gonzáles Donoso, J.M.; Linares, D.; Amédro, F.; Caron, M.; Dupuis, C.V.; Dhondt, A. \& Gartner, S. 2000. Le Crétacé supérieur de la région de Kalaat Senan, Tunesie centrale. Lithobiostratigraphie intégrée: zones d'ammonites, de foraminiféres planctoniques et de nannofossils du Turonien supérieur au Maastrichtien. Bulletin du Centre de Recherches Elf Exploration-Production, 22:359-490.

Sampo, M. 1969. Microfacies and microfossils of the Zagros Area, southwestern Iran (from pre-Permian to Miocene). International Sedimentary Petrographical Series, 12:1-74.

Setudehnia, A. 1972. Stratigraphic Lexicon of Iran. Union International des Sciences Geologiques, 3, ASIE, South-West Iran.

Setudehnia, A. 1978. The Mesozoic sequence in southwest Iran and adjacent areas. Journal of Petroleum Geology, 1:3-42. 
Sliter, W.V. 1989. Biostratigraphic zonation for Cretaceous planktonic foraminifers examined in thin section. Journal of Foraminiferal Research, 19:1-19.

Smit, J. 1982. Extinction and evolution of planktic foraminifera after a major impact at the Cretaceous/Tertiary boundary. Earth and Planetary Science Letters, 74:155-170.

Smit, J. 1999. The global stratigraphy of the Cretaceous-Tertiary boundary impact ejecta. Annual Reviews of Earth and Planetary Science, 27:75-113.

Smit, J. 2004. The section of the Barranco del Gredero (Caravaca, SE Spain): a crucial section for the Cretaceous/Tertiary boundary impact extinction hypothesis. Journal of Iberian Geology, 31:181-193.

Soldan, D.M.; Petrizzo, M.R.; Premoli Silva, I. \& Cau, A. 2011. Phylogenetic relationships and evolutionary history of the Paleogene genus Igorina through parsimony analysis. Journal of Foraminiferal Research, 41:260-284.

Speijer, R.P. 1994. Paleocene sea-level fluctuations recorded in benthic foraminiferal assemblages from Gebel Oweina (Esna, Egypt): local, regional or global patterns? GFF, 116:63-65.

Stoneley, R. 1974. Evolution of the continental margin boundary a former Southern Tethys. In: C.A. Burk and C.L. Darke (eds.) The geology of continental margins, Springer-Verlog, p. 889-902.
Stoneley, R. 1990. The Middle East Basin: a summary overview. In: J. Brooks (ed.) Classic Petroleum Provinces, Geological Society of London, Special Publication, 50:293-298.

Tantawy, A.A.; Keller, G.; Adatte, T.; Stinnesbeck, W.; Kassab, A. \& Schulte, P. 2001. Maastrichtian to Paleocene (Dakhla Formation) depositional environment of the Western Desert in Egypt: sedimentology, mineralogy and integrated micro- and macrofossil biostratigraphies. Cretaceous Research, 22:795-827.

Toumarkine, M. \& Luterbacher, H.P. 1985. Palaeocene and Eocene planktonic Foraminifera. In: H.M. Bolli; J.B. Saunders \& K. Perch-Neilsen (eds.) Plankton Stratigraphy, Cambrige University Press, p. 87-154.

Wynd, J.G. 1965. Biofacies of the Iranian oil consortium agreement area. Tehran, Iranian Oil Operating Companies, Geological and Exploration Division, 89 p. (Report 1082).

Zahiri, A.H. 1982. Maastrichtian microplankton of well Abteymur-1, southwest Iran. Tehran, National Iranian Oil Company, Exploration Division, 21 p. (Report 226).

Ziegler, M.A. 2001. Late Permian to Holocene paleofacies evolution of the Arabian plate and its hydrocarbon. GeoArabia, 6:445-505.

Received in August, 2012; accepted in March, 2013. 